\title{
Pseudosection modeling and U-Pb geochronology on Piranga schists: role of Brasiliano Orogeny in the Southeastern Quadrilátero Ferrífero, Minas Gerais, Brazil
}

\author{
Yanne da Silva Queiroz * (D), Gláucia Queiroga ${ }^{1}$ (D), Renato de Moraes² (D), Victor Matheus Tavares Fernandes (iD,

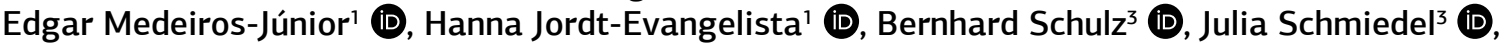 \\ Maximiliano Martins ${ }^{1}$ (D), Marco Paulo de Castro' ${ }^{1}$ (D, Cristiano Lana' (D)
}

\begin{abstract}
In the Southeastern Quadrilátero Ferrífero, a package of metapelitic rocks previously attributed to the Archean Rio das Velhas Supergroup crops out in Piranga locality. This study presents the mineral chemistry and U-Pb-Hf zircon geochronology on foliated staurolite-garnet mica schists. Garnet and staurolite index minerals are syn- to post-kinematic towards the main schistosity. Garnet porphyroblasts display well-developed compositional zoning of $\mathrm{Mg}-\mathrm{Fe}-\mathrm{Mn}-\mathrm{Ca}$, with increase of almandine and pyrope and decrease of spessartine towards the rim, implying in prograde metamorphic pattern. Estimates of P-T values for the metamorphic peak resulted in temperatures between 630 to $650^{\circ} \mathrm{C}$ and pressure around $7 \mathrm{kbar}$. Pseudosections show well-defined stability fields in amphibolite facies, with a metamorphic path displaying progressive increase in P-T conditions. Maximum depositional age of 1,875 $\pm 51 \mathrm{Ma}$ is established for the Piranga mica schists pointing to a depositional history that is younger than those previously described. Metamorphic Cambrian ages characterize the strong influence of deformational processes related to the final stages of Brasiliano Orogeny in the Southeastern Quadrilátero Ferrifero.
\end{abstract}

KEYWORDS: São Francisco Craton; Pelitic rocks; Pseudosection; U-Pb zircon and monazite geochronology; Lu-Hf isotopes.

\section{INTRODUCTION}

Geochronological and petrological studies are essential in ancient and polydeformed cratonic areas, such as Quadrilátero Ferrífero - QF (Alkmim \& Marshak 1998). QF is a significant iron ore province in the world and is located in the Southern edge of São Francisco Craton (SFC), in Minas Gerais State (Fig. 1), Brazil, fringed to the East by the Neoproterozoic Araçuaí Orogen and to the South by

\footnotetext{
Supplementary data

Supplementary data associated with this article can be found in the online version: Supplementary Table A1, Supplementary Table A2, Supplementary Table A3, Supplementary Table A4, Supplementary Table A5 and Supplementary Table A6.
}

\footnotetext{
${ }^{1}$ Departamento de Geologia, Escola de Minas, Universidade Federal de Ouro Preto - Ouro Preto (MG), Brazil.

E-mails: yannequeiroz@gmail.com; glauciaqueiroga@yahoo.com.br; vmtfernandes@gmail.com; edgar.junior@ufop.edu.br; hanna_jordt@yahoo.com.br; maximilianomartins@yahoo.com.br; marco_pcastro@yahoo.com; cristianodeclana@gmail.com

${ }^{2}$ Departamento de Mineralogia e Geotectônica, Instituto de Geociências, Universidade de São Paulo - São Paulo (SP), Brazil.E-mail: rmoraes@usp.com

${ }^{3}$ Institut für Mineralogie der TU Bergakademie - Freiberg/Saxony, Germany E-mails: bernhard.schulz@mineral.tu-freiberg.de; j.schmiedel@hotmail.de

${ }^{*}$ Corresponding author.
}

the Paleoproterozoic Mineiro Belt. The Paleoproterozoic history of QF witnessed the convergence of distinct groups of arcs and microcontinents (Noce et al. 2007, Barbosa \& Sabaté 2004, Teixeira et al. 2015, Aguilar et al. 2017, Cutts et al. 2018). The Rhyacian-Orosirian Orogeny (ca. 2.1$2.0 \mathrm{Ga}$ ) formed structures and overprinted the old QF (Alkmim \& Marshak 1998, Alkmim \& Teixeira 2017). In addition, QF was also tectonically overprinted in parts by the Brasiliano tectonic event (ca. 630-490 Ma) (PedrosaSoares et al. 2007, Alkmim \& Teixeira 2017, Aguilar et al. 2017, Cutts et al. 2018).

Detailed metamorphic studies in Eastern QF metasedimentary sequences are scarce, especially in Piranga region, which is the focus of this paper (Fig. 1). In general, metamorphic grade is higher in the QF Eastern portion and closer to igneous intrusions and uplift zones of the crystalline basement (Dorr II 1964, Herz 1978, Jordt-Evangelista et al. 1992, Marshak et al. 1992), mostly related to the Rhyacian-Orosirian Orogeny (Fig. 1). Aguilar et al. (2017) and Cutts et al. (2018) obtained Paleoproterozoic ages for monazite, titanite, and zircon grains for basement and supracrustal rocks, suggesting a Rhyacian-Orosirian overprint (Fig. 1). However, the influence of Brasiliano Orogeny on the supracrustal deformation and metamorphism has not been well documented. Chemale Jr. et al. (1994) and Alkmim \& Marshak (1998) have pointed a Neoproterozoic influence based on structural studies. Th-U-Pb in situ monazite dating from pelitic schists in upper units of QF (Schmiedel 2015, Fig. 1) reported ages 
between 490 and $510 \mathrm{Ma}$, suggesting an influence from the early Paleozoic event.

The stratigraphic positioning of Piranga metapelites is based on field mapping (Raposo 1991, 1998) and requires determination of timing and P-T metamorphic peak conditions. We present an integrated study of metamorphism and geochronology on three samples of staurolite-garnet mica schists from Southeastern QF, providing new insights on the stratigraphic setting and role of the Brasiliano Orogeny in the QF scenario. This is a major issue because the QF is a large, complex, and significant cratonic portion in the continents.

\section{GEOLOGICAL SETTING}

The SFC (Almeida 1977) in Eastern Brazil was formed between 3.2 and $2.7 \mathrm{Ga}$ (Carneiro et al. 1998) and comprises the largest and best-preserved shield exposure in South America platform, as seen in Figure 1 (Farina et al. 2015). It is subdivided into Archean to Paleoproterozoic blocks sectioned by Paleoproterozoic sutures (Teixeira \& Figueiredo 1991, Barbosa \& Sabaté 2004, Oliveira et al.2010) and Neoproterozoic Araçuaí, Ribeira, and Brasília fold-belts (Pedrosa-Soares et al. 2001, Heilbron et al. 2010, Dardenne 2000, Pimentel et al. 2000, Valeriano et al. 2004). QF is the Southern portion of SFC and comprises several Archean granitoid-gneisses complexes and
Archean to Paleoproterozoic supracrustal sequences, as well as large iron and gold deposits (Lobato et al. 2001).

The four main lithostratigraphic units of QF (Alkmim \& Marshak 1998, Fig. 2) are described as follows:

- Archean granite-gneiss-migmatitic complexes mainly composed of kilometer-scale tonalite-trondhjemite-granodiorite (TTG) cores, which are metamorphosed in amphibolite facies and are locally migmatized (Noce 1995, Alkmim \& Marshak 1998). The main magmatism periods within QF are Santa Bárbara event (ca. 3.2 Ga, Lana et al. 2013), followed by Rio das Velhas I (ca $2.9 \mathrm{Ga}$ ) and II (ca 2.8-2.7 Ga) (Hartmann et al. 2006, Koglin et al. 2014, Farina et al. 2015, Moreira et al. 2016), and then by Mamona I (ca 2.7 Ga) and II (ca 2.6-2.5 Ga) (Farina et al. 2015). In Piranga region, the Archean Santo Antônio do Pirapetinga Complex (SAPC) is the oldest lithostratigraphic unit (Fig. 3), which is an individual unit in the sense of Raposo (1991), although the complex is partially similar to Rio das Velhas Supergroup. The SAPC is composed of TTG gneiss with intercalations of metabasite and meta-ultrabasite and subordinated quartzite and iron formation;

- Archean Rio das Velhas Supergroup (RVS) is mainly composed of metaigneous and low-to-medium metasedimentary rocks, which are considered a greenstone belt. The RVS can be subdivided into Nova Lima and Maquiné Groups

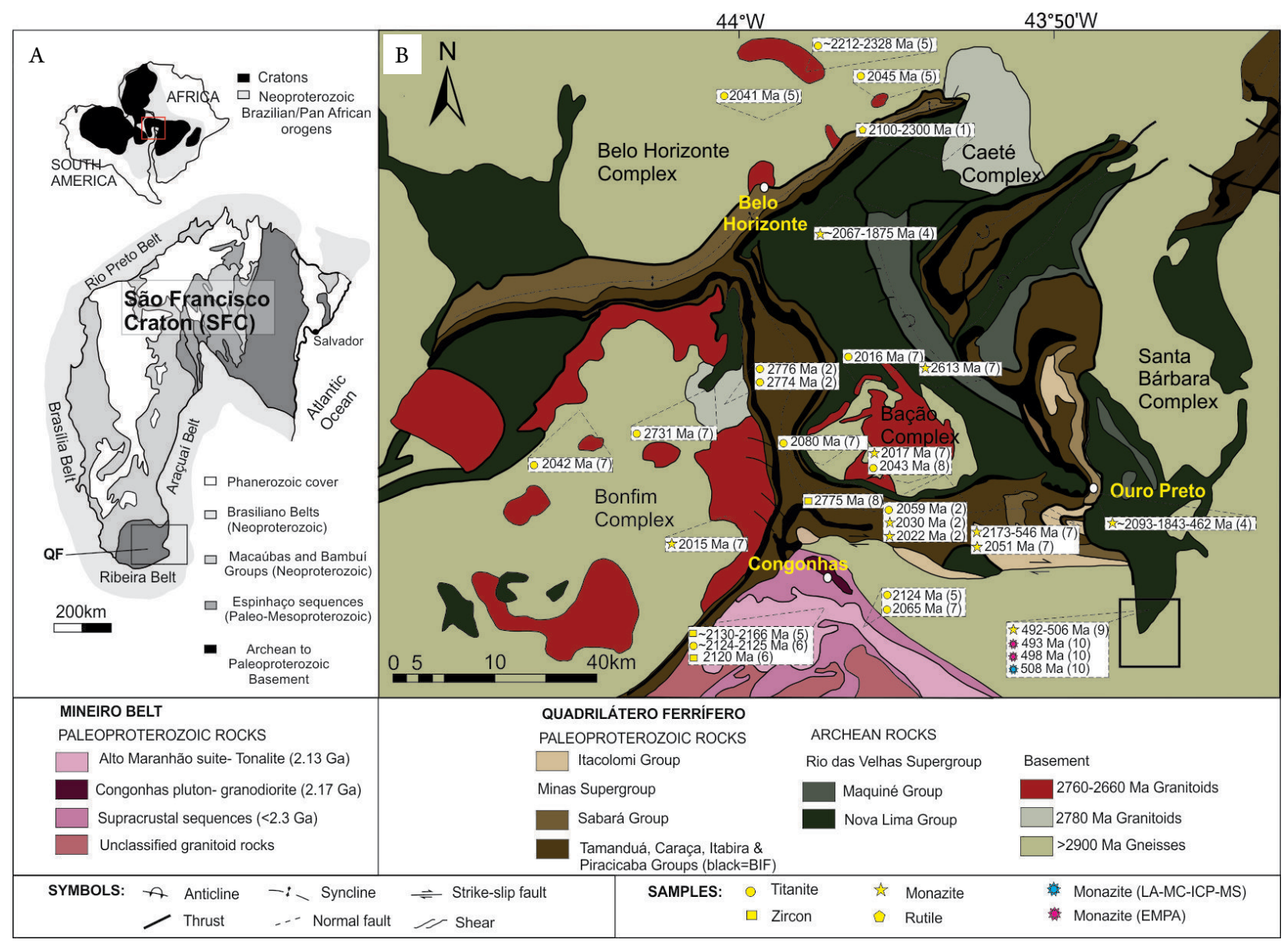

Figure 1. (A) Geological map of São Francisco Craton and surrounding Brasiliano orogenic belts highlighting the Quadrilátero Ferrífero (QF) (box in A) (taken from Alkmim \& Martins-Neto 2012); (B) Geological map with the main lithostratigraphic units of QF and previous published metamorphic ages. Focused area is indicated by black box (based on Dorr II 1969, Alkmim \& Martins-Neto 2012, Farina et al. 2016, Aguilar et al. 2017). References: (1) Belo de Oliveira \& Teixeira (1990), (2) Machado et al. (1992), (3) Machado \& Carneiro (1992), (4) Schrank \& Machado (1996a, 1996b), (5) Noce et al. (1998), (6) Seixas et al. (2013), (7) Aguilar et al. (2017), (8) Cutts et al. (2019), (9) Schmiedel (2015), (10) this study. 
(Dorr II 1969). The basal Nova Lima Group consists of (meta) mafic and ultramafic volcanic rocks containing pillow basalts and komatiites, as well as intercalations of banded iron formation, ferruginous chert, felsic volcanoclastic rocks, and a package of clastic sediments. This basal group is unconformably overlain by Maquiné Group, which consists of shallow marine to alluvial (meta) sandstone, conglomerate, and pelitic rocks (Baltazar \& Pedreira 1998). Available geochronological data for Nova Lima volcanoclastic rocks range from 2,792 to 2,751 Ma, whereas the maximum sedimentation age was dated at 2,749 $\pm 7 \mathrm{Ma}$ (Machado et al. 1992, Noce et al. 2005, Hartmann et al. 2006). Maquiné Group sedimentary rocks have a maximum depositional age of ca. 2,730 (Moreira et al. 2016). In Piranga, Raposo (1991) subdivided the RVS into lower (metavolcanic rocks), middle (feldspar-quartz-mica schist with variable amounts of garnet, staurolite and kyanite), and upper (quartzite and minor metaconglomerate lenses) units.

- Paleoproterozoic Minas Supergroup is ca. 6km-thick package of clastic and chemical sedimentary rocks, which are metamorphosed in greenschist to amphibolite facies (Alkmim \& Marshak 1998), unconformably over the Rio das Velhas Supergroup (Farina et al. 2015). The basal sequence of Minas Supergroup is composed of Caraça (extensive metaconglomerate, metarenite and phyllite), Itabira (itabirite and dolomitic marble), and Piracicaba (metarenite and metapelite) Groups. These involve continental and marine sediments (Dorr II 1969, Renger et al. 1995) and represent the development stage of a passive margin (Schorscher 1992, Canuto 2010). The upper sequence contains Sabará Group of deep-to shallow-marine and deltaic strata, also turbidite and conglomerate. This group is interpreted as a submarine deposit that marks the inversion of passive margin basin (Alkmim \& Marshak 1998). From U-Pb isotopic data, Minas Supergroup has a maximum depositional age between 2,600 and 2,100 Ma (Alkmim \& Marshak 1998, Nunes 2016, Dopico et al. 2017);

- Itacolomi Group is a ca. $1.8 \mathrm{~km}$-thick succession of metasandstone, metaconglomerate and metapelitic rocks, overlying the Minas Supergroup across a regional unconformity (Dorr II 1969, Alkmim \& Martins-Neto 2012). The Itacolomi Group is an alluvial complex, locally submerged by a lake or shallow sea (Alkmim 1987). According to Barbosa (1968) and Dorr II (1969), the sediments of Itacolomi Group are a typical "molasse deposit". Marshak et al. (1992), Alkmim \& Marshak (1998), Alkmim \& Martins-Neto (2012) point out this unit was deposited in small intermontane basins during the Rhyacian-Orosirian orogenetic collapse phase. Most sediments in conglomerates of the Itacolomi Group were generated during the Rhyacian-Orosirian Orogeny, with minor Archean contribution (Machado et al. 1996, Alkmim \& Marshak 1998). The most probable sources of Itacolomi Group are Mantiqueira Complex (2,119 \pm 16 to 2,084 $\pm 13 \mathrm{Ma}$, Noce et al. 2007), Ritápolis - Alto Maranhão Suite (2,130 Ma, Seixas et al. 2013), Serrinha Tiradentes Batholith $(2,227 \pm 22$ to 2,204 $\pm 11 \mathrm{Ma}$, Ávila et al.2014, Teixeira et al.2015), and Juiz de Fora Complex $(2,041 \pm 7$ to $2,137 \pm 19 \mathrm{Ma}$; Noce et al. 2007).

QF also includes several granitic bodies, pegmatite and mafic dykes (Farina et al. 2015). In Piranga region, the Piranga Syenite (Jordt-Evangelista \& Peres 1997,

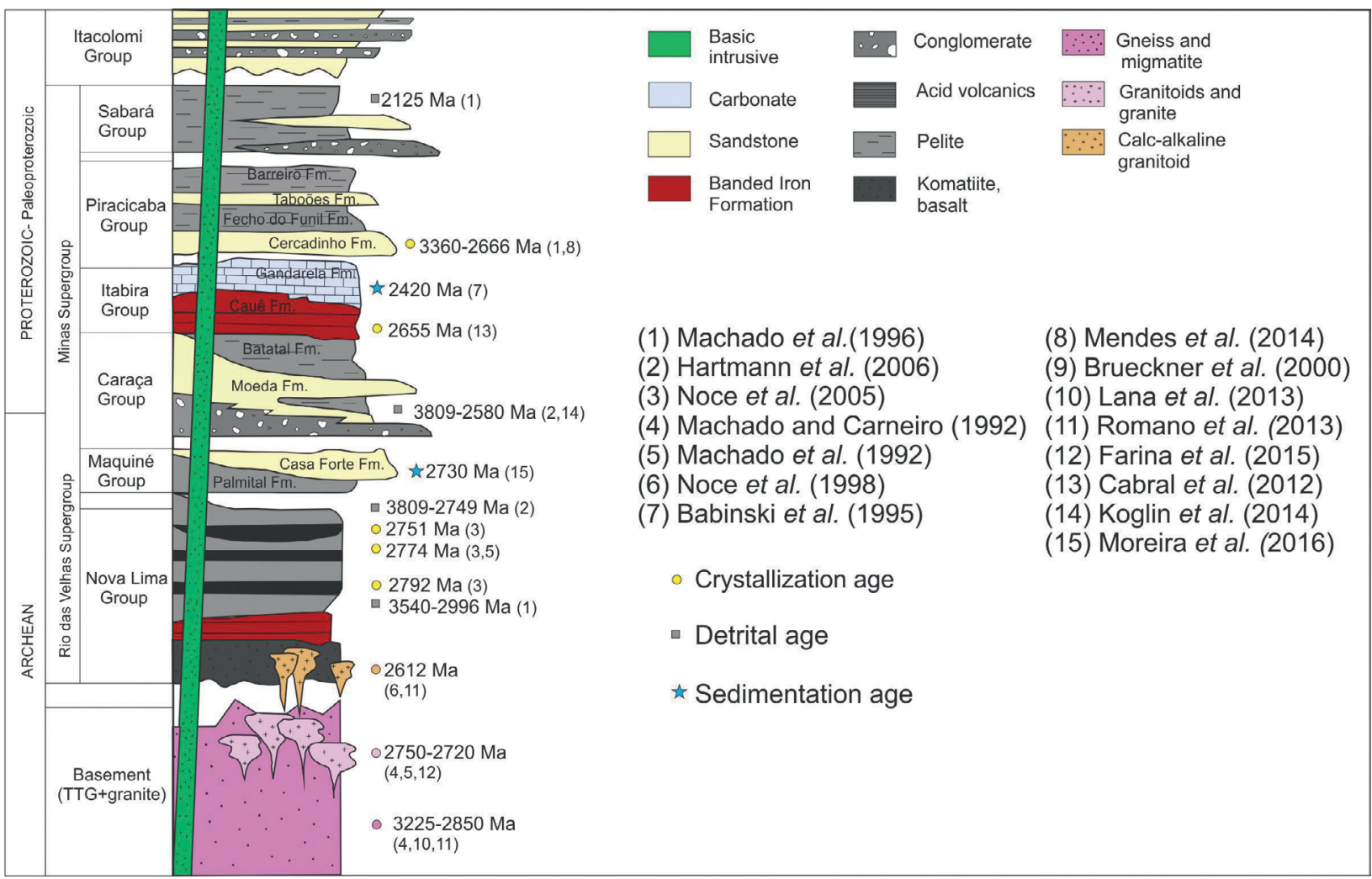

Source: modified after Alkmim \& Marshak (1998), Farina et al. (2016), Dopico et al. (2017).

Figure 2. Lithostratigraphic column of Quadrilátero Ferrífero displaying major lithological units. 
Jordt-Evangelista et al. 2000, Silva 2014) and Ressaquinha Complex (Teixeira 1985, Raposo 1998) complete the regional framework (Fig. 3).

\section{ANALYTICAL METHODS}

The study of selected rocks attributed initially to Rio das Velhas Supergroup included petrographic and microstructural characterization, mineral chemistry, geothermobarometric calculations, pseudosection modeling, and Th-U-Pb zircon and monazite dating. Analyses were performed in three metapelite samples: ME04, ME07 and ME08 (location in Fig. 3).

\section{Mineral chemistry, geothermobarometry, and pseudosection modeling}

Three-hundred quantitative analyses of garnet and staurolite porphyroblasts and coexisting muscovite, biotite, plagioclase, and opaques were carried out with two distinct electron microprobes: JEOL JXA-8900L instrument, Institut für Werkstoffwissenschaft at Freiberg, Germany; and JEOL JXA8230 equipment, Microscopy and Microanalysis Laboratory

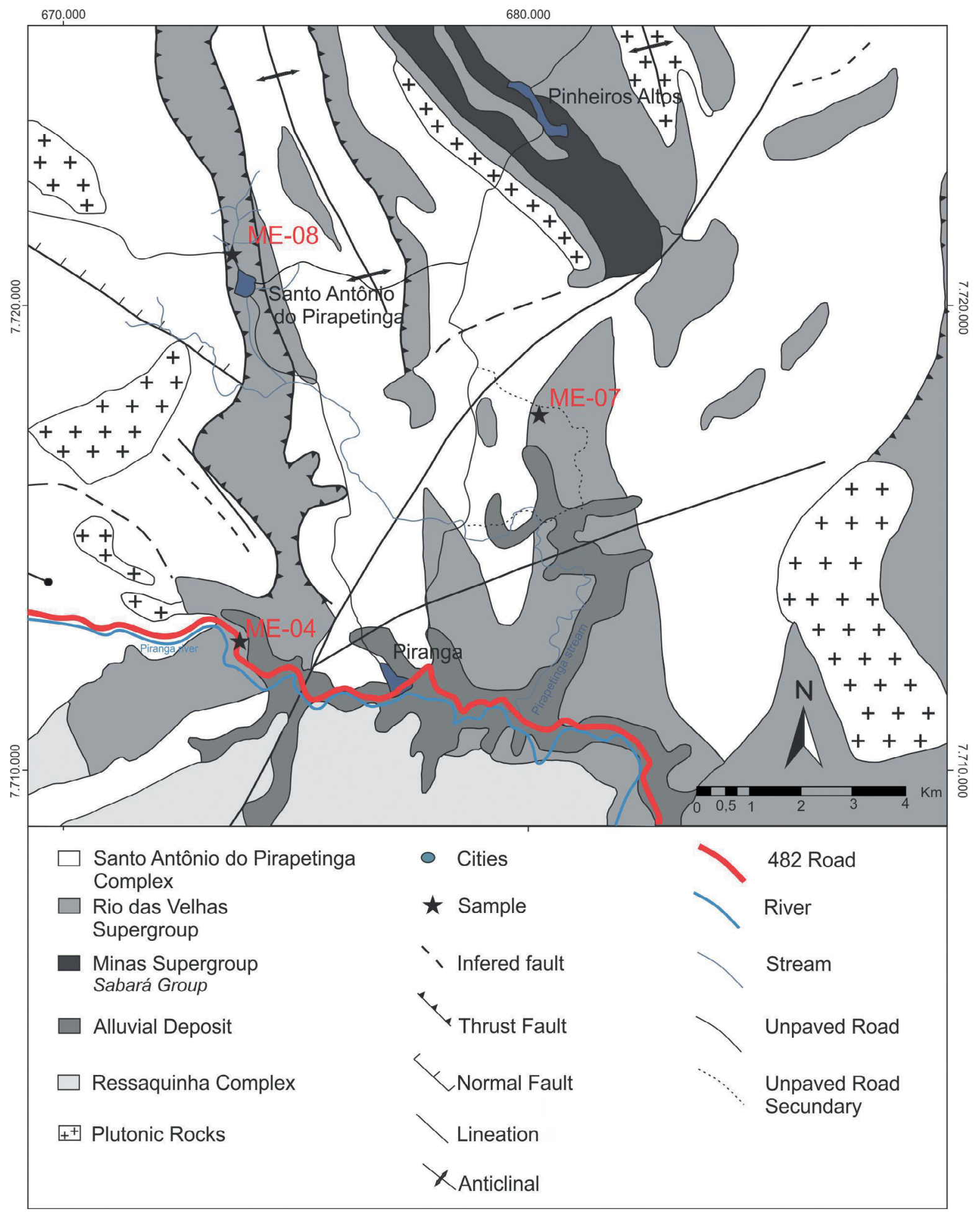

Source: modified from Raposo (1998).

Figure 3. Simplified geological map of the study area including the location of sampled rocks. 
(LMIc) at Universidade Federal de Ouro Preto (UFOP), Brazil. For both dataset analyses, the electron beam was set at $15 \mathrm{kV}$, $20 \mathrm{nA}, 5-10 \mu \mathrm{m}$, and the common matrix ZAF (Z - atomic number, A - absorption, $\mathrm{F}$ - fluorescence) corrections were applied. Total iron content was taken as FeO. The elements analyzed and natural standards (in parentheses) at the German instrument were as follow: $\mathrm{Si}$ (wollastonite), $\mathrm{Na}$ (albite), $\mathrm{K}$ (orthoclase), $\mathrm{Mn}$ (bustamite), $\mathrm{Ti}$ (rutile), $\mathrm{Mg}$ and $\mathrm{Ca}$ (diopside), $\mathrm{Al}$ (garnet), and Fe (hematite). Those used at the UFOP were: $\mathrm{Si}$ (quartz), $\mathrm{K}$ (microcline), $\mathrm{Mn}\left(\mathrm{MnO}_{2}\right), \mathrm{Ti}$ (rutile), $\mathrm{Mg}$ (olivine), $\mathrm{Ca}$ (fluor-apatite), $\mathrm{Al}$ (corundum), $\mathrm{Fe}$ (Fe metal), $\mathrm{F}\left(\mathrm{CaF}_{2}\right), \mathrm{Cl}$ (scapolite), $\mathrm{Ba}\left(\mathrm{BaSO}_{4}\right), \mathrm{Cr}$ (chromite), $\mathrm{Sr}$ (strontianite), and $\mathrm{Zn}$ (gahnite). Counting times on peak and background were $10 / 5$ seconds for all elements in both instruments.

Pressure and temperature conditions were interpreted using the average P-T method with THERMOCALC 3.33 software from Powell \& Holland $(1988,1994)$.

Pseudosections were calculated using the bulk composition from the two most representative samples of staurolite-garnet mica schist (ME04 and ME07), and the modeling was done using Theriak-Domino software (De Capitani \& Petrakakis 2010) in combination with Holland \& Powell (1998) thermodynamic dataset. Calculations were based on the chemical system $\mathrm{MnO}-\mathrm{Na}_{2} \mathrm{O}-\mathrm{CaO}-\mathrm{K}_{2} \mathrm{O}-\mathrm{FeO}-\mathrm{MgO}-\mathrm{Al}_{2} \mathrm{O}_{3}-\mathrm{SiO}_{2}-\mathrm{H}_{2} \mathrm{O}$ (Mn-CNKFMASH) for both samples, because it represents the bulk composition of the studied metapelites. Excess water and quartz were considered in all calculations. Abbreviations for minerals in the descriptions follow Whitney \& Evans (2010). Modeling used the activity-composition (A-X) relationships of White et al. (2005) for garnet and biotite, Holland \& Powell (1998) for staurolite, Holland \& Powell (2003) for plagioclase, Mahar et al. (1997) and Holland \& Powell (1998) for chlorite, Coggon \& Holland (2002) for white mica. Petrography indicates that the oxides are in low oxidation; therefore, $\mathrm{Fe}^{3+}$ was not used. According to White et al. (2000), the addition of $\mathrm{Fe}_{2} \mathrm{O}_{3}$ to the system affects isograds in $\mathrm{Fe}^{3+}$ rich metapelitic rocks, but the studied samples are low in this cation. Small effect on silicate stability occurs by adding $\mathrm{TiO}_{2}$ to typical pelitic bulk compositions (White et al. 2000).

\section{Geochronology}

\section{In situ Th-U-Pb monazite dating}

In situ analyses of $\mathrm{Th}, \mathrm{U}$, and $\mathrm{Pb}$ for calculating monazite model ages, as well as for $\mathrm{Ca}, \mathrm{Si}, \mathrm{LREE}$, and $\mathrm{Y}$ for evaluating mineral chemistry were carried out on the JEOL JXA-8230 microprobe at the Microscopy and Microanalysis Laboratory (LMIc, UFOP), using an acceleration voltage of $20 \mathrm{kV}$. Beam current was set at $150 \mathrm{nA}$ at a beam diameter of $1 \mu \mathrm{m}$. The $\mathrm{M} \alpha$ lines for $\mathrm{Th}$ and $\mathrm{Pb}$ and the $\mathrm{M} \beta$ line for $\mathrm{U}$ of a PETH crystal were selected for analysis. Absolute errors at counting times of 30 ( $\mathrm{U}$ and $\mathrm{Th}$ ) and 50 seconds $(\mathrm{Pb})$ are typically $0.12 \mathrm{wt} \%$ for $\mathrm{Pb}$ and $\mathrm{U}$ and $0.20 \mathrm{wt} \%$ for Th. Chosen lines were $\mathrm{L} \alpha$ for La, Y, Ce; $\mathrm{L} \beta$ for Pr, Sm, Nd, Gd; and K $\alpha$ for P, Si and Ca. Calibration of $\mathrm{PbO}$ was done on a covelite $(\mathrm{PbS})$ standard, while $\mathrm{U}$ was calibrated with a U-glass $\left(4.54 \mathrm{wt} \% \mathrm{U}_{3} \mathrm{O}_{8}\right)$. Orthophosphates of the Smithsonian Institution were used as standards for REE analyses (Jarosewich \& Boatner 1991, Donovan et al. 2003), except for Th, which was calibrated using a monazite grain. The monazite chemical model ages were determined using the $\mathrm{ThO}_{2}{ }^{*}-\mathrm{PbO}$ isochron method (CHIME) of Suzuki \& Adachi (1991, 1994) and Suzuki et al. (1994), in which the age is calculated from the regression line slope in $\mathrm{ThO}_{2}{ }^{*} v s$. $\mathrm{PbO}$ coordinates forced through zero, in a JEOL software (MonaziteAge, program for calculating monazite ages, version 2.03 - McSwiggen \& Asociates). $\mathrm{ThO}_{2}{ }^{*}$ is $\mathrm{ThO}_{2}$ plus $\mathrm{O}_{2}$ equivalents after Suzuki et al. (1994). Madmon, a monazite from a pegmatite in Madagascar, acted as a reference for monazite data (U-Pb SHRIMP age at $496 \pm 9 \mathrm{Ma}$, around $10 \mathrm{wt} \% \mathrm{ThO}_{2}$; Schulz et al. 2007, Schulz \& Schüssler 2013).

\section{Laser ablation multi-collector inductively coupled plasma mass spectrometry $\mathrm{U}-\mathrm{Pb}$ and $\mathrm{Lu}-\mathrm{Hf}$ in zircon and $\mathrm{U}-\mathrm{Pb}$ in monazite}

Three samples of staurolite-garnet-mica schist were selected for $\mathrm{U}-\mathrm{Pb}$ zircon and monazite dating. All samples were processed at UFOP by conventional methods of crushing, screening, and concentration of heavy minerals. Zircon and monazite were hand-picked and mounted on an epoxy circular disc that was polished in sequence. Cathodoluminescence (CL) images were obtained using an electron microscope JEOL JSM 6510 at the Microscopy and Microanalysis Laboratory (LMIc, UFOP), under $20 \mathrm{kV}$.

$\mathrm{U}-\mathrm{Pb}$ isotopic analyses were performed in zircon grains using an Element II instrument coupled to a CETAC 213 laser ablation system at the Isotope Geochemistry Laboratory from UFOP. For these determinations, laser fired at a frequency of $10 \mathrm{~Hz}$, using energy of $6 \mathrm{~J} / \mathrm{cm}^{2}$ and $\mathrm{He}$ as a sample carrier gas. Background data were acquired for 20 seconds followed by a 50 -second laser ablation. Laser spot size was $20 \mu \mathrm{m}$. The primary standard used was GJ-1 zircon (Jackson et al. 2004); BB zircon (Santos et al. 2017, Lana et al. 2017) acted as a secondary reference. Time-resolved signal data were processed by Glitter software package (van Achterbergh et al. 2001), while Isoplot software (Ludwig 2003) was used for data processing. Corrections of background, downhole fractionation, instrumental mass bias drift, and common $\mathrm{Pb}$ were processed using an in-house spreadsheet modified from Gerdes \& Zeh (2006). Errors for all ages are reported at $2 \sigma$ level.

Same routine adopted for zircons was followed for monazite grains, except for the spot size $(30 \mu \mathrm{m})$ and reference materials (USGS, Aleinikoffet al.2006, Diamantina, Gonçalves et al.2018).

$\mathrm{Lu}-\mathrm{Hf}$ isotopic analyses in zircon grains were carried out using the LA-MC-ICP-MS instrument (Photon machine 193/ Neptune Thermo Scientific) at the Isotope Geochemistry Laboratory, UFOP. We selected two samples, ME04 and ME08, and used, wherever possible, the same zircon domain previously analyzed for U-Pb isotopes. GJ-1 (Jackson et al. 2004), BB (Santos et al. 2017), and 91500 (Wiedenbeck et al. 1995) acted as standards and were repeatedly measured during the analyses of unknown samples to check the instrument reliability and stability. The ${ }^{176} \mathrm{Lu}$ decay constant of $1.867 \times 10^{-11}$ year ${ }^{-1}$ provided by Söderlund et al. (2004) was used to calculate initial ${ }^{176} \mathrm{Hf} /{ }^{177} \mathrm{Hf}$ ratios. 


\section{Samples description}

Field and petrographic features presented below are based on the first author's master thesis and on unpublished data of Schmiedel (2015).

\section{Sample ME08}

Sample ME08 is located 500 meters North of downtown Santo Antônio do Pirapetinga, in the bed of a tributary to Pirapetinga River (UTM 673634/7721035; Fig. 3). Schists at
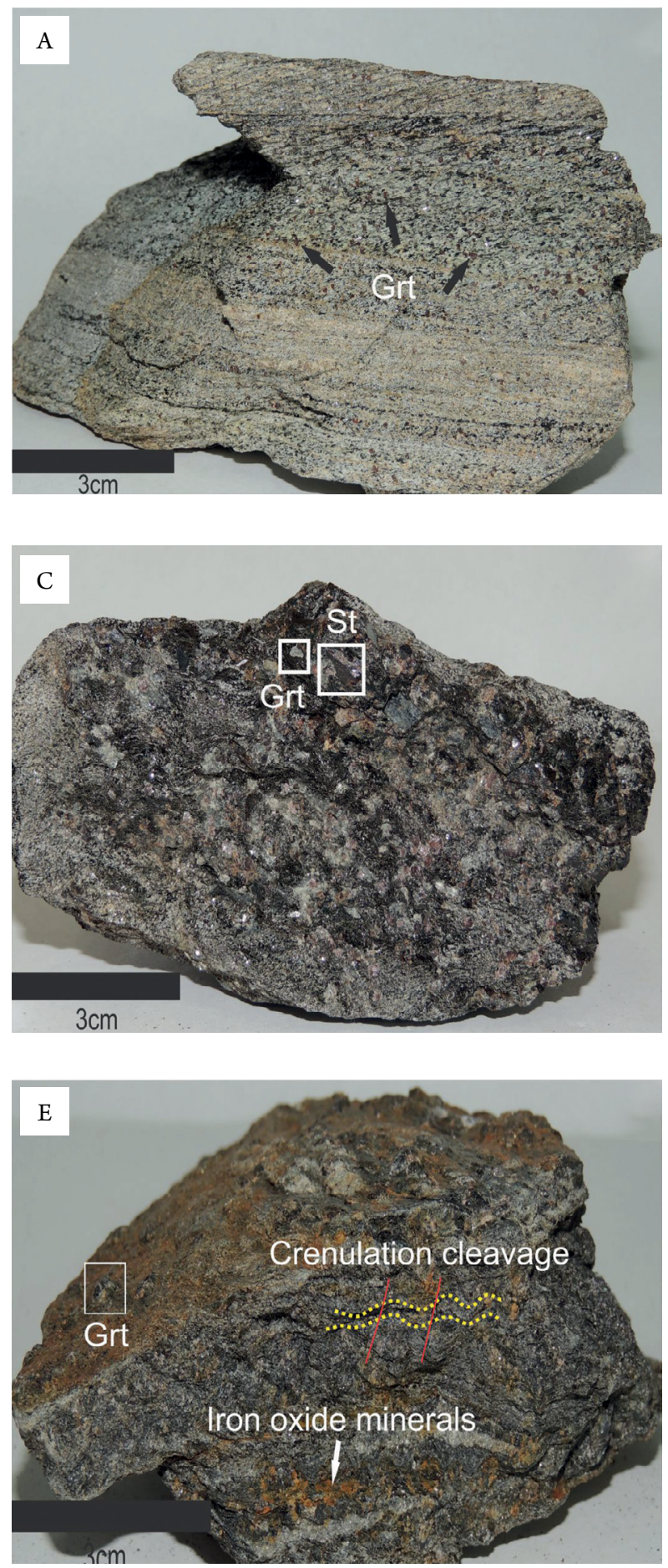

Si: foliation; $\mathrm{Si}+1$ : crenulation cleavage.

Figure 4. Hand specimen and thin section photomicrographs. (A) ME08 hand sample with domains of garnet (Grt) embedded in the foliated matrix. (B) ME08 thin section showing large syn-kinematic garnet porphyroblasts and post-kinematic staurolite (parallel polarizers). (C) ME04 hand specimen with prismatic staurolite and subhedral garnet porphyroblasts. (D) ME04 thin section displaying syn- to- postkinematic garnet and staurolite porphyroblasts. Biotite (Bt) and white mica (Wm) marking the main foliation (parallel polarizers). (E) ME07 hand specimen of staurolite-garnet mica schist showing crenulation cleavage and nodules of garnet (Grt) that protrude from the foliation surface. (F) ME07 photomicrograph displaying a well-marked crenulation cleavage (parallel polarizers). this place are banded, intercalating biotite-rich and poor zones (Fig. 4A). Other fabrics observed closely are either homogeneous, fine-grained or platy schistose. Some metapelite domains have a large amount of garnet encompassed by the foliated matrix. ME08 main minerals are quartz, plagioclase, biotite, garnet, and staurolite with subordinate muscovite, chlorite, epidote, tourmaline, apatite, and opaque minerals. Zircon and monazite are common accessory phases. The staurolite-garnet-bearing mica schist displays well-developed,

tightly folded schistosity. Large garnet porphyroblasts are up to $0.5 \mathrm{~cm}$ in length and have oriented inclusions of quartz and opaque minerals, registering syn-kinematic growth (Fig. 4B). Inclusions in staurolite porphyroblasts are mostly oriented parallel to main foliation (helicitic microstructure), which implies post-kinematic growth. The matrix is composed of biotite + quartz \pm muscovite \pm plagioclase, mostly plainly foliated, and flows around the coarser, rigid garnet and staurolite porphyroblasts.

\section{Sample MEO4}

Sample ME04 occurs on the main road 482 to Conselheiro Lafaiete along Piranga River (UTM 673661/7712589; Fig. 3). The sample is a mica schist composed of quartz, biotite, muscovite, garnet, plagioclase, chlorite and staurolite, with accessories apatite, tourmaline, monazite, zircon and opaque minerals. Carbonate and sericite are alteration products of plagioclase. Sample ME04 shows quartz venules and is weakly banded. Its dark appearance is due to biotite. In hand specimen, there are large prismatic staurolite and subhedral garnet porphyroblasts embedded in a fine-to medium-grained micaceous foliated matrix (Fig. 4C). Garnet is syn-kinematic and staurolite is post-kinematic in relation to the main schistosity (Fig. 4D). Decussate muscovite and chlorite also occur.

\section{Sample ME07}

Sample ME07 outcrops about $7 \mathrm{~km} \mathrm{NE}$ of Piranga, close to Lagoinha creek, a small tributary to Pirapetinga River (UTM 680263/7716826; Fig. 3). In hand sample, there are nodules of garnet protruding from weathered foliation sheets. The staurolite-garnet mica schist is weakly banded, locally folded. Crenulation cleavage is present in some parts, which are well evidenced in thin section (Figures 4E-F). Sample ME07 is composed of quartz, plagioclase, biotite, garnet, and chlorite with minor amounts of staurolite, muscovite and iron oxide minerals, resulting in the red-orange color of the rock. Zircon, monazite, and apatite are accessory minerals. Garnet porphyroblasts are syn-kinematic with foliation as indicated by the inclusion pattern. $\mathrm{Sn}+1$ crenulation is marked by muscovite, biotite, and chlorite (Fig. 4F).

\section{RESULTS}

\section{$\mathrm{U}-\mathrm{Pb}$ and Lu-Hf (laser ablation multi- collector inductively coupled plasma mass spectrometry) isotope data on zircon}

We present the geochronological data for two metapelite samples using $\mathrm{U}-\mathrm{Pb}$ and $\mathrm{Lu}-\mathrm{Hf}$ isotopic methods through the laser ablation multi-collector inductively coupled plasma mass spectrometry (LA-MC-ICP-MS). Complete data tables are available in Supplementary Tables A1 and A2. Location of ME04 and ME08 mica schists are shown in Figure 3. Zircon crystals from both samples display similar isotopic patterns; therefore, ME04 and ME08 data are described together, except where noted.
Detrital zircons from the schist are yellowish to brownish, prismatic to equidimensional, rounded to subhedral and have maximal length of $250 \mu \mathrm{m}$ (Fig. 5). Most crystals show high ${ }^{232} \mathrm{Th} /{ }^{238} \mathrm{U}$ ratio, ranging from 0.042 to 0.668 , and oscillatory zoning in CL images (Fig. 5), which represent magmatic grains in the source. After data reduction, 164 spots were selected for age calculations. Both samples recorded a predominant source at ca. $2,100 \mathrm{Ma}(80-85 \%$ of all analyzed zircons plot in the 1,960-2,260 Ma interval), as seen in Figure 6. Four other minor zircon populations in ME04 sample, indicated by the following age intervals, are recognized: 1,860-1,890 Ma (2\%), 2,200-2,380 Ma (10\%), 2,540-2,760 Ma (4\%) and around $3,150 \mathrm{Ma}(1 \%)$. For ME08, minor zircon populations are: $1,810-1,920 \mathrm{Ma}(2 \%), 2,230-2,460 \mathrm{Ma}(8 \%), 2,510-2,770 \mathrm{Ma}$ (7\%), and 2,930-2,980 (2\%). Four of the youngest concordant zircon grains from samples ME04 and ME08 suggest a maximum sedimentation age of $1,875 \pm 51 \mathrm{Ma}$.

$\mathrm{Lu}-\mathrm{Hf}$ analyses were carried out on the same crystals previously used for $\mathrm{U}-\mathrm{Pb}$ isotopes to constrain provenance. Both samples present a significant variation of $\varepsilon \mathrm{Hf}$. The $\varepsilon \mathrm{Hf}(\mathrm{t})$ versus ${ }^{207} \mathrm{~Pb} /{ }^{206} \mathrm{~Pb}$ (age) plot (Fig. 7) shows positive and negative $\varepsilon \mathrm{Hf}$ values, indicating a mixture of crustal and juvenile sources. Among 132 analyzed grains, 112 Paleoproterozoic grains dated at ca. 2,500-2,000 Ma yielded $\varepsilon \mathrm{Hf}_{(\mathrm{t})}=-10.7$ to +6 (Fig. 7), with $\mathrm{Hf}_{\mathrm{DM}}$ at 2,178 to 3,351 Ma. These $\varepsilon \mathrm{Hf}_{(\mathrm{t})}$ values indicate a large contribution from older continental crust and juvenile rocks related to Araçuaí Orogen basement and Mineiro Belt (Noce et al. 2007, Seixas et al. 2013). Grains older than 2,750 Ma show negative $\varepsilon H f$ values, suggesting crustal source related to the Archean crystalline basement (Lana et al. 2013, Farina et al. 2015, Albert et al. 2016, Fonseca 2017).

\section{Metamorphic history}

To reconstruct the metamorphic history and find the metamorphic peak of the studied samples, we performed chemical analyses on selected minerals and geothermobarometric calculations using the P-T average mode of THERMOCALC and pseudosections. Complete data tables, including the oxide compositions of each mineral, are available in Supplementary Table A3. A summary of geothermobarometric data and geochronological ages is shown in Table 1.

\section{Mineral chemistry and average $\mathrm{P}$-T thermobarometry}

\section{Sample ME08}

Large garnet porphyroblasts from sample ME08 have distinct zoning profiles and well-marked rim-core-rim structure. The chemical zoning pattern of garnet shows increase of almandine (61.8 to 77.4 endmember\%) and pyrope (6.0 to $14.3 \%$ ) and decrease of spessartine (16.7 to $2.6 \%$ ) and grossular (17.1 to $5.8 \%$ ), as seen in Figure 8A, from core to rim, reflecting growth under increasing temperature. The garnet formula unit is: $\left(\mathrm{Fe}_{1.86-2.31} \mathrm{Mg}_{0.18-0.43} \mathrm{Ca}_{0.17-0.52} \mathrm{Mn}_{0.08-0.51}\right) \mathrm{Al}_{1.96-2.0} \mathrm{Si}_{3.0-3.05} \mathrm{O}_{12}$. Granoblastic plagioclase in matrix is homogeneous and classified as oligoclase $\left(\mathrm{An}_{12.48-25.26}\right)$; the average formula unit is $\left(\mathrm{K}_{0.00 \text { - }}\right.$ $\left.\left.{ }_{0.08} \mathrm{Na}_{0.74-0.83} \mathrm{Ca}_{0.12-0.27}\right)\left(\mathrm{Al}_{0.17-0.25} \mathrm{Si}_{0.75-0.83}\right) \mathrm{AlSi}_{2} \mathrm{O}_{8}\right)$. Biotite flakes 
approximate to lepidomelane member in the solid solution annite-phlogopite, with $\mathrm{X}_{\mathrm{Mg}}$ varying between 0.43 and 0.46 . The average formula unit is $\left(\mathrm{Na}_{0.04-0.07} \mathrm{~K}_{0.80-0.89} \mathrm{Ca}_{0.00-0.01}\right)\left(\mathrm{Al}_{0.36 \text { - }}\right.$ $\left.{ }_{0.43} \mathrm{Mg}_{1.22-1.32} \mathrm{Fe}_{1.08-1.15}\right)\left(\mathrm{Al}_{1.21-1.28} \mathrm{Si}_{2.72-2.79}\right) \mathrm{O}_{10}(\mathrm{OH}, \mathrm{F})_{2}$

Pressure and temperature values obtained for ME08 mica schist are $649 \pm 26^{\circ} \mathrm{C}$ and $7.5 \pm 0.9 \mathrm{kbar}$, corresponding to medium-to-upper amphibolite facies.

\section{Sample ME04}

Sample ME04 has large staurolite and garnet porphyroblasts set in a fine-to medium-grained lepidoblastic matrix. Garnet zonation profiles display decrease of spessartine (21.0 to 0.3 endmember\%) and grossular (11.1 to $6.5 \%$ ) molecules from core to rim. Almandine has a minimum of $62.6 \%$ in the core, increasing to $78.2 \%$ towards the rim. Pyrope content varies from 6.3 to $15.32 \%$ from core to rim (Fig. $8 \mathrm{~B}$ ). These features point to a prograde growth. Garnet formula unit is:
$\left(\mathrm{Fe}_{1.88-2.38} \mathrm{Mg}_{0.19-0.46} \mathrm{Ca}_{0.20-0.32} \mathrm{Mn}_{0.03-0.63}\right) \mathrm{Al}_{1.97-2.01} \mathrm{Si}_{3.0-3.04} \mathrm{O}_{12}$. Matrix granoblastic plagioclase composition ranges from $\mathrm{An}_{16.37}$ to $\mathrm{An}_{23.14}$, oligoclase (average formula unit is $\left(\mathrm{K}_{0.00-0.11} \mathrm{Na}_{0.75-0.84} \mathrm{Ca}_{0.17-0.24}\right)$ $\left.\left(\mathrm{Al}_{\text {0.15-0.23 }} \mathrm{Si}_{\text {0.77-0.85 }}\right) \mathrm{AlSi}_{2} \mathrm{O}_{8}\right)$. Matrix biotite flakes (lepidomelane endmember) show homogeneous composition with $\mathrm{X}_{\mathrm{Mg}}=$ 0.41-0.44, displaying average formula unit of $\left(\mathrm{Na}_{0.03-0.06} \mathrm{~K}_{0.87-0.92}\right)$ $\left(\mathrm{Al}_{0.38-0.43} \mathrm{Mg}_{1.20-1.30} \mathrm{Fe}_{\text {1.07-1.17 }}\right)\left(\mathrm{Al}_{1.24-1.29} \mathrm{Si}_{2.71-2.76}\right) \mathrm{O}_{10}(\mathrm{OH}, \mathrm{F})_{2}$. Analyzed staurolite porphyroblast has $\mathrm{X}_{\mathrm{Fe}}$ between 0.79 and $0.81, \mathrm{MnO}$ content of 0.026 to $0.123 \%$, and a general formula unit of $\left(\mathrm{Fe}_{1.60-1.64} \mathrm{Mg}_{0.37-0.42}\right)\left(\mathrm{Al}_{8.57-8.66} \mathrm{Ti}_{0.05-0.08}\right) \mathrm{Si}_{3.91-3.97} \mathrm{O}_{22}(\mathrm{OH})_{2}$.

ME04 sample reached a peak temperature of $640 \pm 25^{\circ} \mathrm{C}$ and a maximum pressure of $7.9 \pm 0.9 \mathrm{kbar}$, within medium-to-upper amphibolite facies.

\section{Sample MEO7}

ME07 syn-kinematic garnet porphyroblasts also show well-developed zoning with an increase of almandine (72.4 to

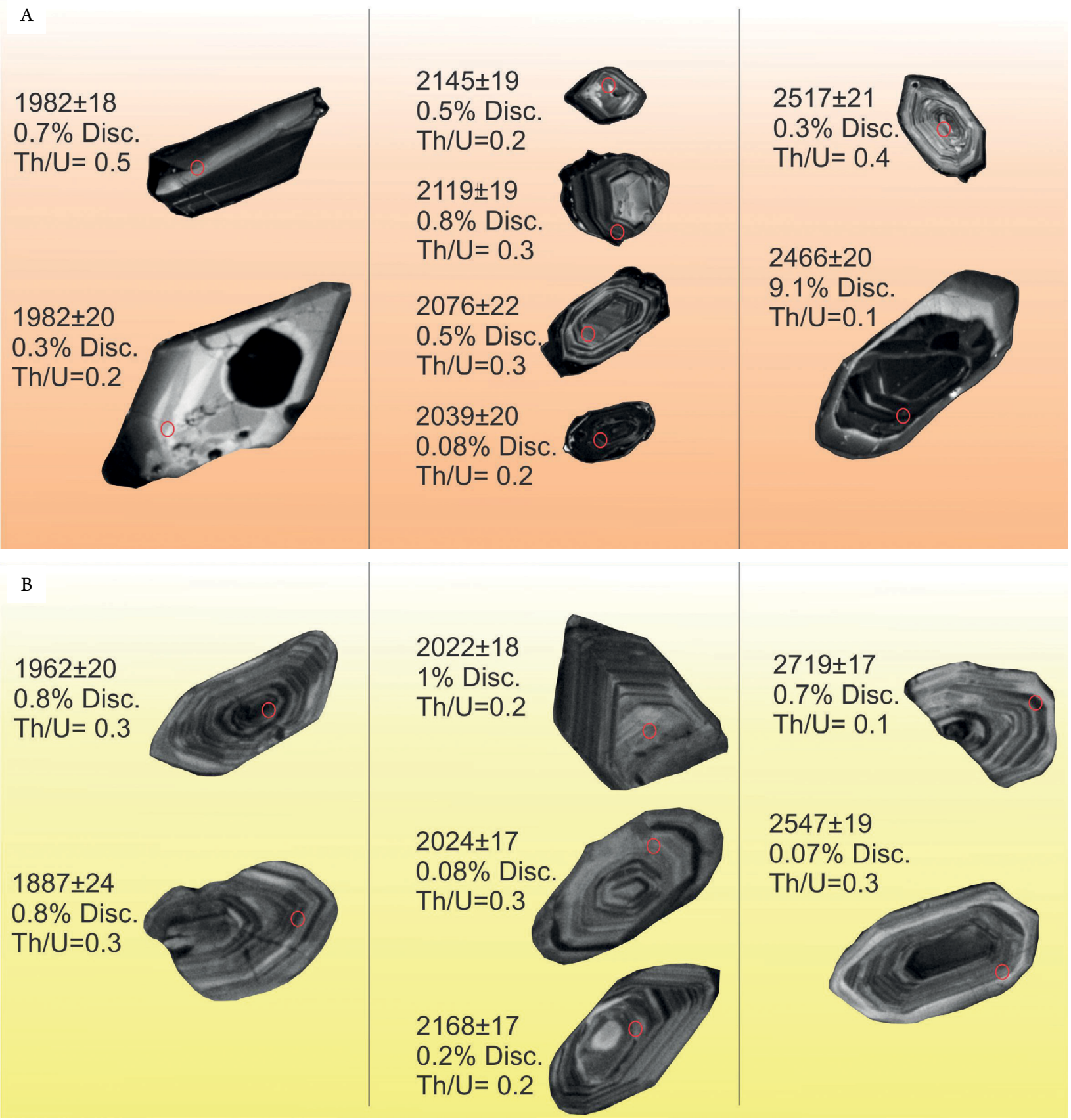

Figure 5. Selected cathodoluminescence (CL) zircon images for samples (A) ME08 and (B) ME04. The red circle represents the analyzed spot. 
76.7 endmember\%) and pyrope ( 8.7 to $20.4 \%$ ) and decrease of spessartine ( 7.1 to $0.3 \%$ ) and grossular ( 11.0 to $4.8 \%$ ), from core to rim (Fig. $8 \mathrm{C}$ ). Garnet average formula unit

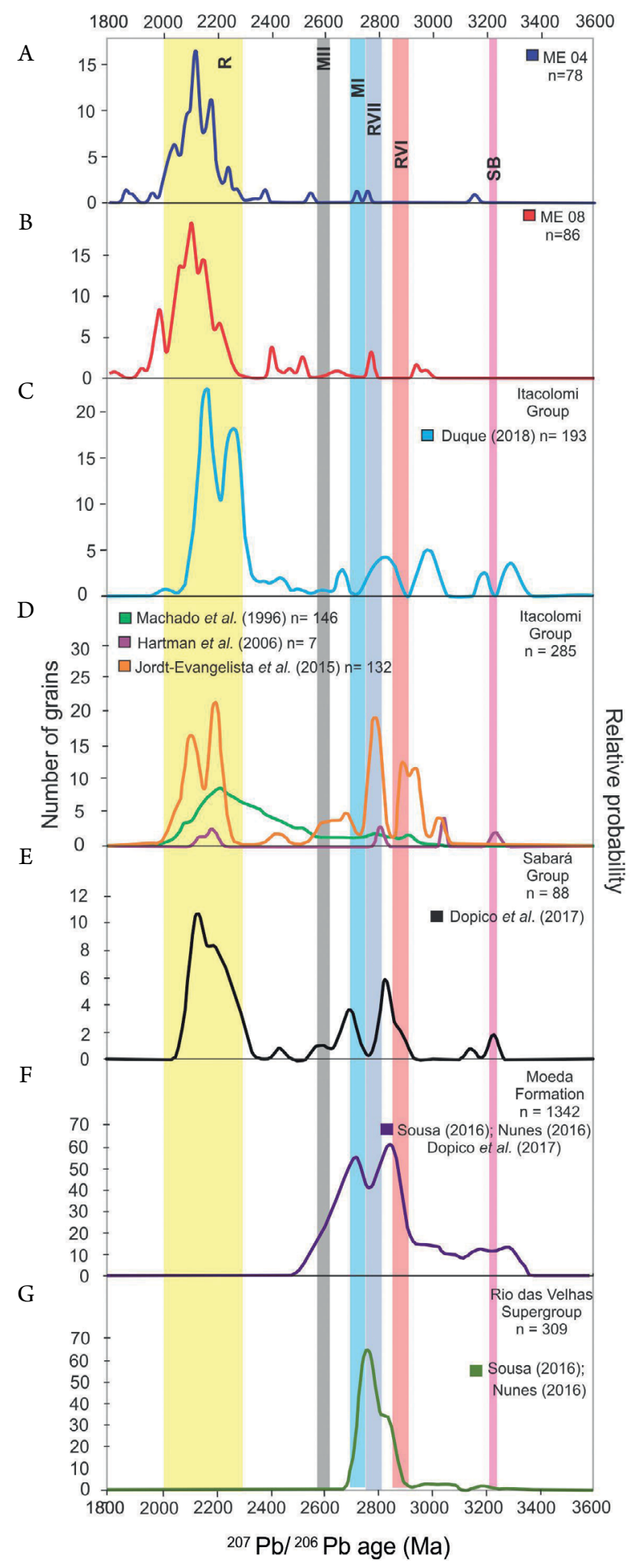

SB: Santa Bárbara; RVI: Rio das Velhas I; RVII: Rio das Velhas II; MI: Mamona I; MII: Mamona II; R: Rhyacian.

Figure 6. (A and B) Frequency histogram and probability curves for all the available $\mathrm{U}-\mathrm{Pb}$ data for the studied metapelites. ( $\mathrm{C}$ to G) Frequency histograms and probability curves for all available $\mathrm{U}-\mathrm{Pb}$ detrital zircon ages for Rio das Velhas Supergroup, Moeda Formation, Sabará and Itacolomi Groups (based on Machado et al. 1996, Hartmann et al. 2006, Jordt-Evangelista et al. 2015, Sousa 2016, Nunes 2016, Dopico et al. 2017, Duque 2018). Age intervals indicated as (1) Santa Bárbara, (2) Rio das Velhas I, (3) Rio das Velhas II, (4) Mamona, (4b) Late Mamona are based on Lana et al. (2013) and Farina et al. $(2015,2016)$. is $\left(\mathrm{Fe}_{2.15-2.28} \mathrm{Mg}_{0.26-0.61} \mathrm{Ca}_{0.14-0.33} \mathrm{Mn}_{0.01-0.21}\right) \mathrm{Al}_{2.0-2.07} \mathrm{Si}_{2.96-3.00} \mathrm{O}_{12}$. Two coalescent garnet crystals display progressive growth with $\mathrm{MgO}$ increasing and $\mathrm{MnO}$ decreasing from core to rim. This feature is documented in the characteristic X-ray maps available in Figure 9. Granoblastic matrix plagioclase is homogeneous $\left(\mathrm{An}_{17.8-28.3}\right.$; average formula unit is $\left(\mathrm{Na}_{0.72-0.78} \mathrm{Ca}_{0.22-0.28}\right)\left(\mathrm{Al}_{0.24}{ }^{-}\right.$ $\left.{ }_{0.30} \mathrm{Si}_{0.70-0.77}\right) \mathrm{AlSi}_{2} \mathrm{O}_{8}$ ) and classified as oligoclase. Biotite flakes have $\mathrm{X}_{\mathrm{Mg}}$ between 0.49 and 0.52 . Their formula unit is $\left(\mathrm{Na}_{0.04}\right.$ $\left.{ }_{0.08} \mathrm{~K}_{\text {0.75-0.84 }} \mathrm{Ca}_{0.00-0.01}\right)\left(\mathrm{Cr}_{\text {0.00-0.01 }} \mathrm{Al}_{\text {0.34-0.42 }} \mathrm{Mg}_{\text {1.47-1.51 }} \mathrm{Fe}_{\text {0.88-1.06 }}\right)\left(\mathrm{Al}_{1.22-}\right.$ $\left.{ }_{1.34} \mathrm{Si}_{2.66-2.78}\right) \mathrm{O}_{10}(\mathrm{OH}, \mathrm{F})_{2 .}$. Staurolite crystals display $\mathrm{X}_{\mathrm{Fe}}$ between 0.75 and $0.78, \mathrm{MnO}$ content of 0.002 and $0.05 \%$, and formula unit of $\left(\mathrm{Fe}_{\text {1.35-1.45 }} \mathrm{Mg}_{0.38-0.45}\right)\left(\mathrm{Al}_{\text {8.78-8.96 }} \mathrm{Ti}_{\text {0.04-0.06 }}\right) \mathrm{Si}_{3.79-3.93} \mathrm{O}_{22}(\mathrm{OH})_{2}$.

Estimates of P-T for the ME07 mica schist sample indicates $634 \pm 10^{\circ} \mathrm{C}$ and $7.2 \pm 0.8 \mathrm{kbar}$, medium-to-upper amphibolite facies.

\section{Pseudosection modeling}

The analyzed pelitic schists furnish enough information of their metamorphic P-T path. Quartz, biotite, and oxide inclusions in ME04 and ME07 samples do not constrain any P-T fields of stable mineral assemblage. In all samples, the mineral assemblage fields are in the amphibolite facies, as expected from petrographic characterization and $\mathrm{P}$ and $\mathrm{T}$ calculations (average mode of THERMOCALC). Bulk composition of each sample, used for pseudosection calculation, is available in Supplementary Table A4.

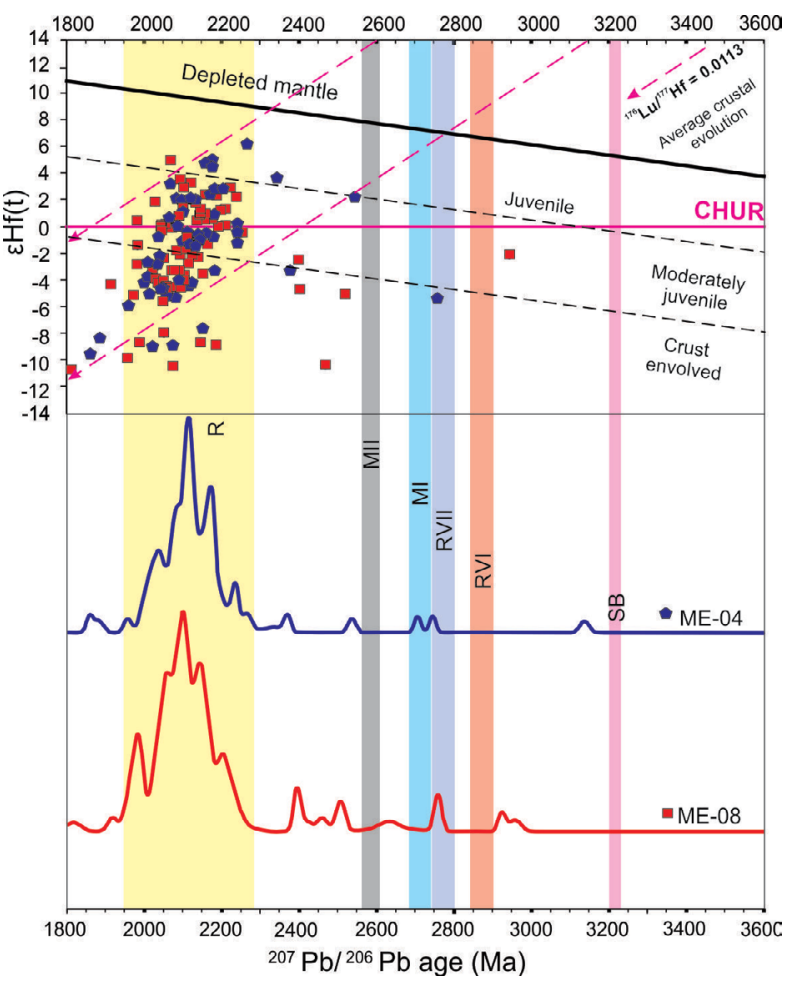

SB: Santa Bárbara; RVI: Rio das Velhas I; RVII: Rio das Velhas II; MI: Mamona I; MII: Mamona II; R: Rhyacian.

Figure 7. $\mathrm{Hf}(\mathrm{t})$ versus ${ }^{207} \mathrm{~Pb} /{ }^{206} \mathrm{~Pb}$ age diagram showing results for detrital zircon from ME04 and ME08 samples. Age intervals indicated as (1) Santa Bárbara, (2) Rio das Velhas I, (3) Rio das Velhas II, (4) Mamona, (4b) Late Mamona are based on Lana et al. (2013) and Farina et al. $(2015,2016)$. References lines on Hf plot are as followed: CHUR based on Bouvier et al. (2008) and DM on Blichert-Toft \& Puchtel (2010). 


\section{Sample ME04}

Pseudosection calculations for sample ME04 show metamorphic peak mineral assemblage field, represented by $\mathrm{Pl}+$ $\mathrm{Grt}+\mathrm{Bt}+\mathrm{Wm}+\mathrm{St}$ (Fig. 10, blue region), with a small variation of temperature and pressure. Due to compositional zonation of garnet crystals, limited $\mathrm{P}-\mathrm{T}$ path was obtained in rim and core. This stabilization field was defined using garnet rim isopleths $\left(\mathrm{X}_{\mathrm{Grs}}\right.$ 0.08-0.09 and $\mathrm{X}_{\mathrm{Sp}}$ 0.05-0.06) that intersect in the stable assemblage field, thus constraining $\mathrm{P}-\mathrm{T}$ peak conditions between $\sim 6.9-7.2 \mathrm{kbar}$ and $\sim 590-620^{\circ} \mathrm{C}$ (Fig. 10).

ME04 mica schist metamorphism began at temperature and pressure conditions of around $540^{\circ} \mathrm{C}$ and $5.0 \mathrm{kbar}$,

Table 1. Summary of geothermobarometric data and related metamorphic ages for the studied mica schists.

\begin{tabular}{|c|c|c|c|c|c|c|}
\hline \multirow[t]{2}{*}{ Sample } & \multicolumn{2}{|c|}{$\begin{array}{c}\text { Average P-T mode of } \\
\text { THERMOCALC } \\
\text { (Powell \& Holland 1988, 1994) }\end{array}$} & \multicolumn{2}{|c|}{$\begin{array}{c}\text { Pseudosection modeling } \\
\text { (De Capitani \& Petrakakis 2010) }\end{array}$} & \multicolumn{2}{|c|}{ U-Pb monazite ages } \\
\hline & $\mathbf{T}\left({ }^{\circ} \mathbf{C}\right)$ & $\mathbf{P}($ kbar $)$ & $\mathbf{T}\left({ }^{\circ} \mathrm{C}\right)$ & $\mathbf{P}($ kbar $)$ & Isotopic age (Ma) & CHIME (Ma) \\
\hline ME04 & $640 \pm 25$ & $7.9 \pm 0.9$ & $590-620$ & $6.9-7.2$ & n.d. & n.d. \\
\hline ME07 & $634 \pm 10$ & $7.2 \pm 0.8$ & $640-655$ & $5.9-7.9$ & $493 \pm 4$ & $508 \pm 27$ \\
\hline ME08 & $649 \pm 26$ & $7.5 \pm 0.9$ & n.d. & n.d. & n.d. & $498 \pm 25$ \\
\hline
\end{tabular}

n.d.: not determined; CHIME: chemical age.
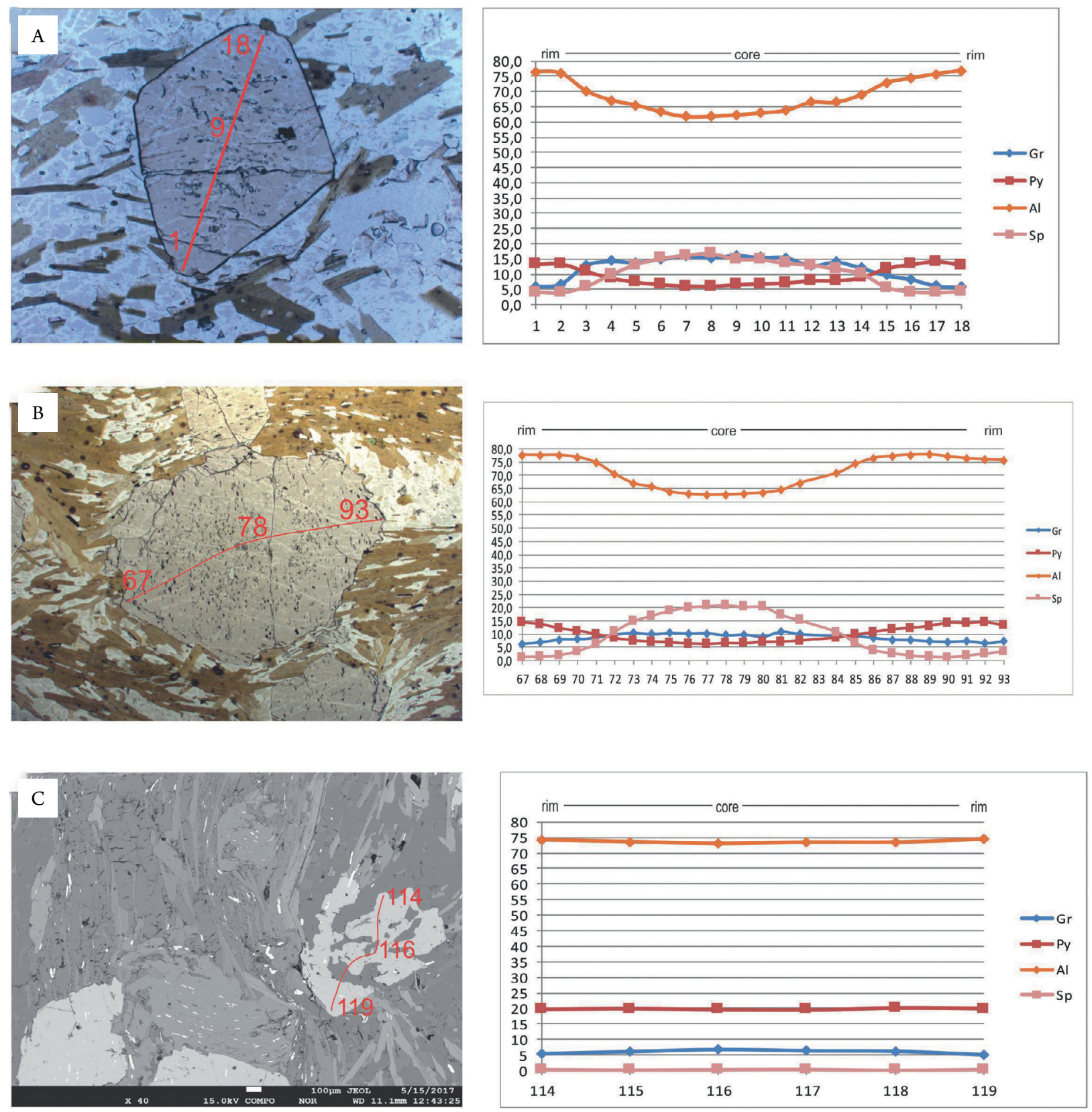

Grs: grossular; Prp: pyrope; Alm: almandine; Sps: spessartine.

Figure 8. Garnet porphyroblasts with the analyzed points in the left and garnet zonation in Grs-Prp-Alm-Sps contents diagram in the right. (A) Sample ME08, (B) Sample ME04 and (C) Sample ME07. 
greenschist to amphibolite facies transition (Fig. 10). This feature can be observed in the green delimited area, marked by the beginning of garnet core growth, highlighted by the intersection of grossular and spessartine isopleths. At this stage, the stable mineral assemblage was composed of $\mathrm{Pl}+\mathrm{Grt}+\mathrm{Bt}$ $+\mathrm{Chl}+\mathrm{Wm}$ (Fig. 10). Initial metamorphic conditions were also in the red region of Figure 10, which shows the intersection of almandine and grossular isopleths. After temperature and pressure increase, chlorite was consumed to form staurolite. This feature is highlighted in the blue area of , in which the mineral assemblage $\mathrm{Pl}+\mathrm{Grt}+\mathrm{Bt}+\mathrm{Wm}+$ St was stable at around $590-620^{\circ} \mathrm{C}$ and $6.9-7.2 \mathrm{kbar}$.

\section{Sample ME07}

Pressure conditions of sample ME07 cover a large interval; however, the temperature field is relatively small, between $560-650^{\circ} \mathrm{C}$. The metamorphic process started at around $560^{\circ} \mathrm{C}$ and $5.6 \mathrm{kbar}$, and the stable mineral assemblage was $\mathrm{Pl}+\mathrm{Grt}+$ $\mathrm{Bt}+\mathrm{Chl}+\mathrm{St}+\mathrm{Wm}$ (Fig. 11, pink circle). Intersection of garnet rim isopleths $\left(\mathrm{X}_{\mathrm{Sp}} 0.004-0.005\right.$ and $\left.\mathrm{X}_{\mathrm{Gr}} 0.04-0.05\right)$ delimit mineral stability field at 640 to $655^{\circ} \mathrm{C}$ and 5.9 to $7.9 \mathrm{kbar}$
(Fig. 11, blue region). These P-T values represent the metamorphic peak conditions of ME07 mica schist.

\section{Monazite dating by laser ablation multi- collector inductively coupled plasma mass spectrometry and electron microprobe}

In order to constrain the metamorphic episode timing that affected the studied metapelitic sequence, we dated monazite grains from two samples using both isotopic and chemical methods (Tab. 1). An epoxy mount of monazite crystals was used for laser analyses; whereas polished thin sections were used for Electron Probe Microanalysis (EPMA).

\section{Isotopic method}

The LA-MC-ICP-MS analyses were carried out in ME07 mica schist. Crystals are rounded to elongated, subhedral, displaying some cracks (Fig. 12A). Diameter ranges from 100 to $200 \mu \mathrm{m}$. Twenty-three points align in the Discordia diagram with an upper intercept at 2,853 $\pm 37 \mathrm{Ma}$ and a lower intercept at $493 \pm 4 \mathrm{Ma}(\mathrm{MSWD}=0.49)$, as seen in Figure 12B, Table 1 and Supplementary Table A5.
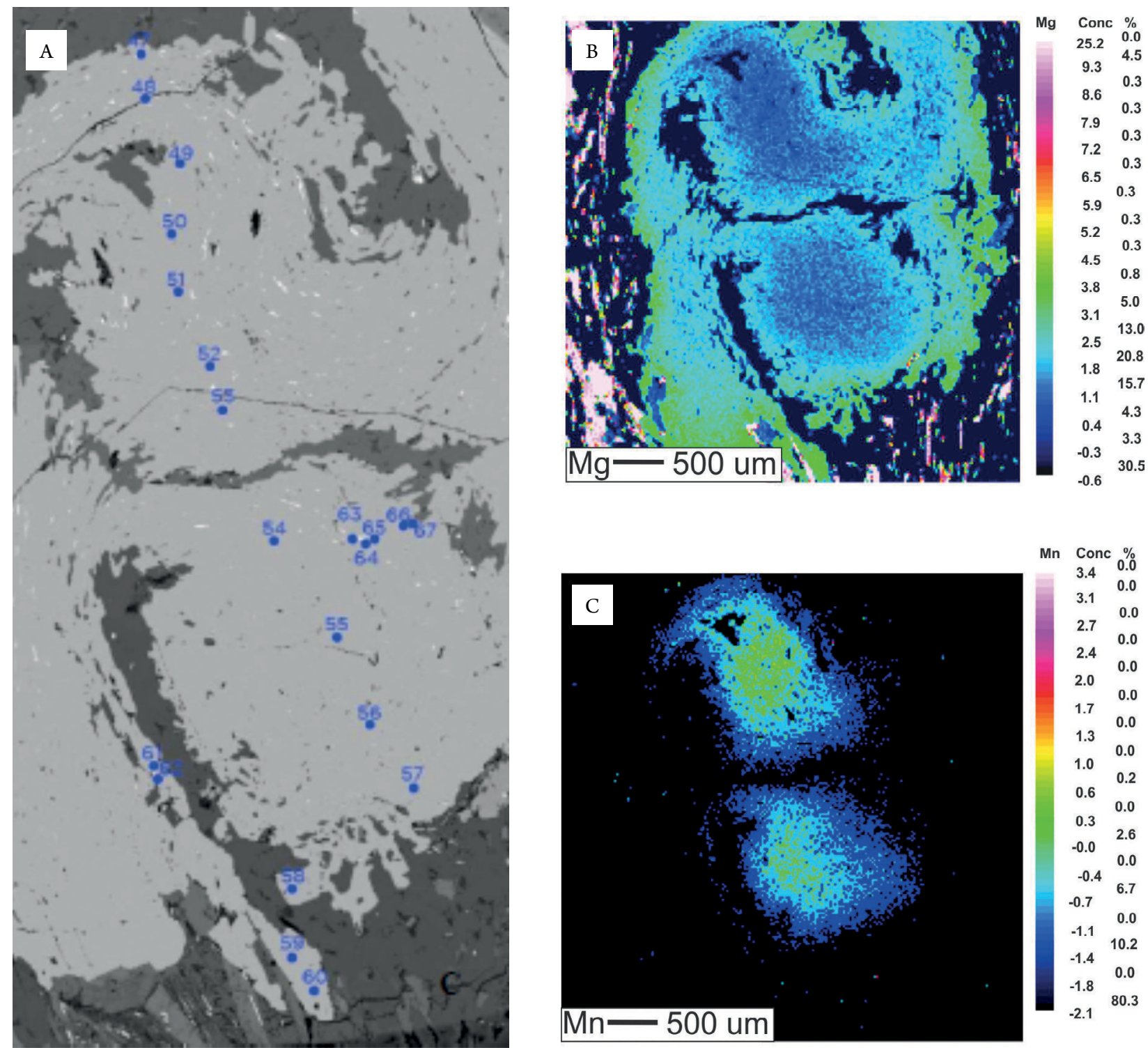

Figure 9. (A) BSE image of coalescent garnets in ME07 mica schist. Blue points are analyzed spots. (B) and (C) Characteristic X-ray compositional maps of $\mathrm{MgO}(\mathrm{B})$ and $\mathrm{MnO}(\mathrm{C})$ contents. 


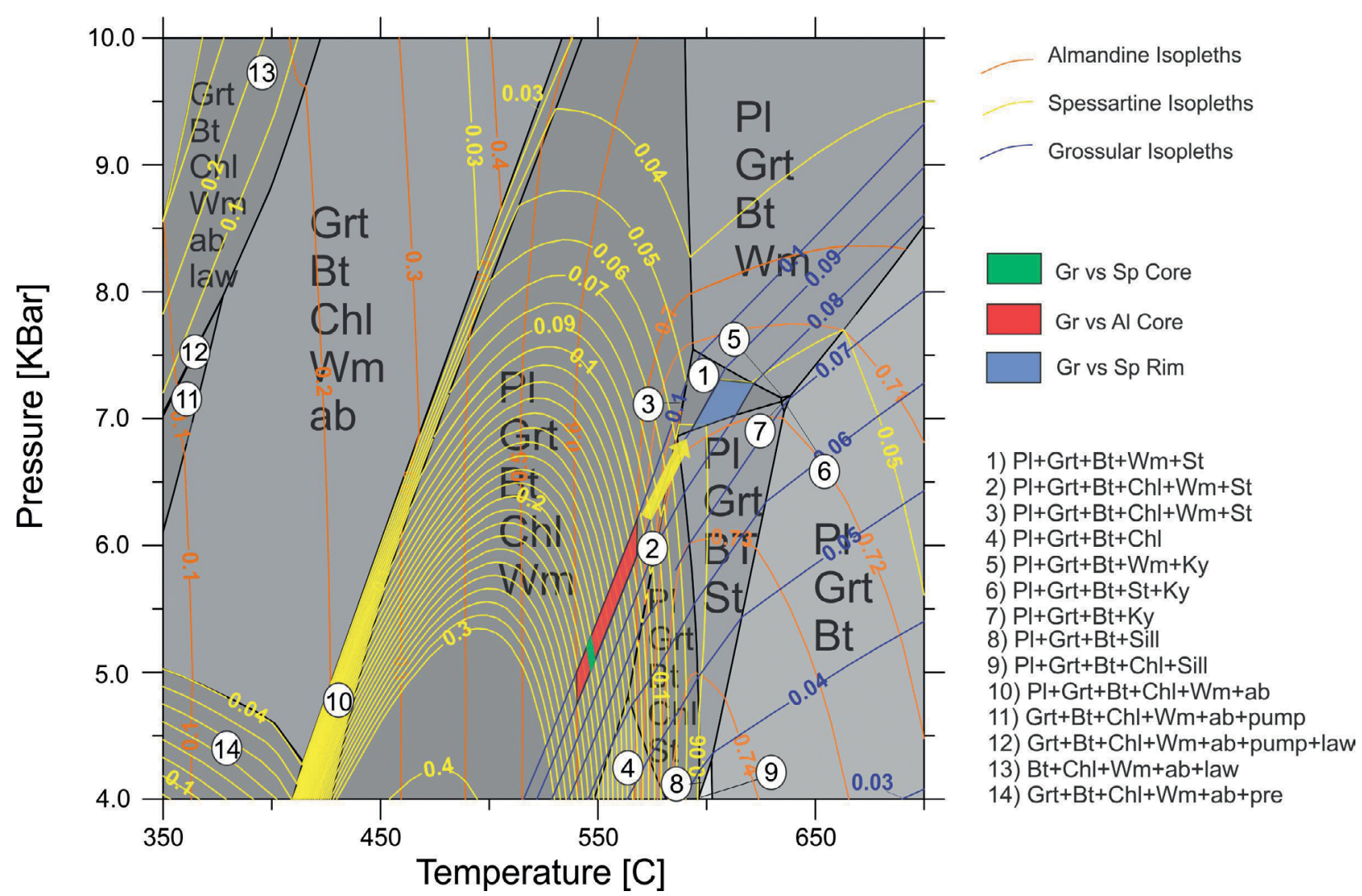

Figure 10. P-T pseudosection modeling for sample ME04. The blue field shows stabilization defined by garnet rim isopleths $\left(\mathrm{X}_{\mathrm{Grs}}-\mathrm{blue}\right.$ lines and $\mathrm{X}_{\mathrm{Sp}}-$ yellow lines). The stable mineral assemblage is $\mathrm{Pl}+\mathrm{Grt}+\mathrm{Bt}+\mathrm{Wm}+\mathrm{St}$. Pink $\left(\mathrm{X}_{\mathrm{Gr}}-\right.$ blue lines and $\mathrm{X}_{\mathrm{Al}}-$ orange lines $)$ and red fields $\left(\mathrm{X}_{\mathrm{Gr}}\right.$ and $\left.\mathrm{X}_{\mathrm{Sp}}\right)$ fields show the stabilization defined by garnet core isopleths. The proposed P-T trajectory is based on garnet composition (yellow arrow). $\mathrm{H}_{2} \mathrm{O}$ and quartz considered in excess.

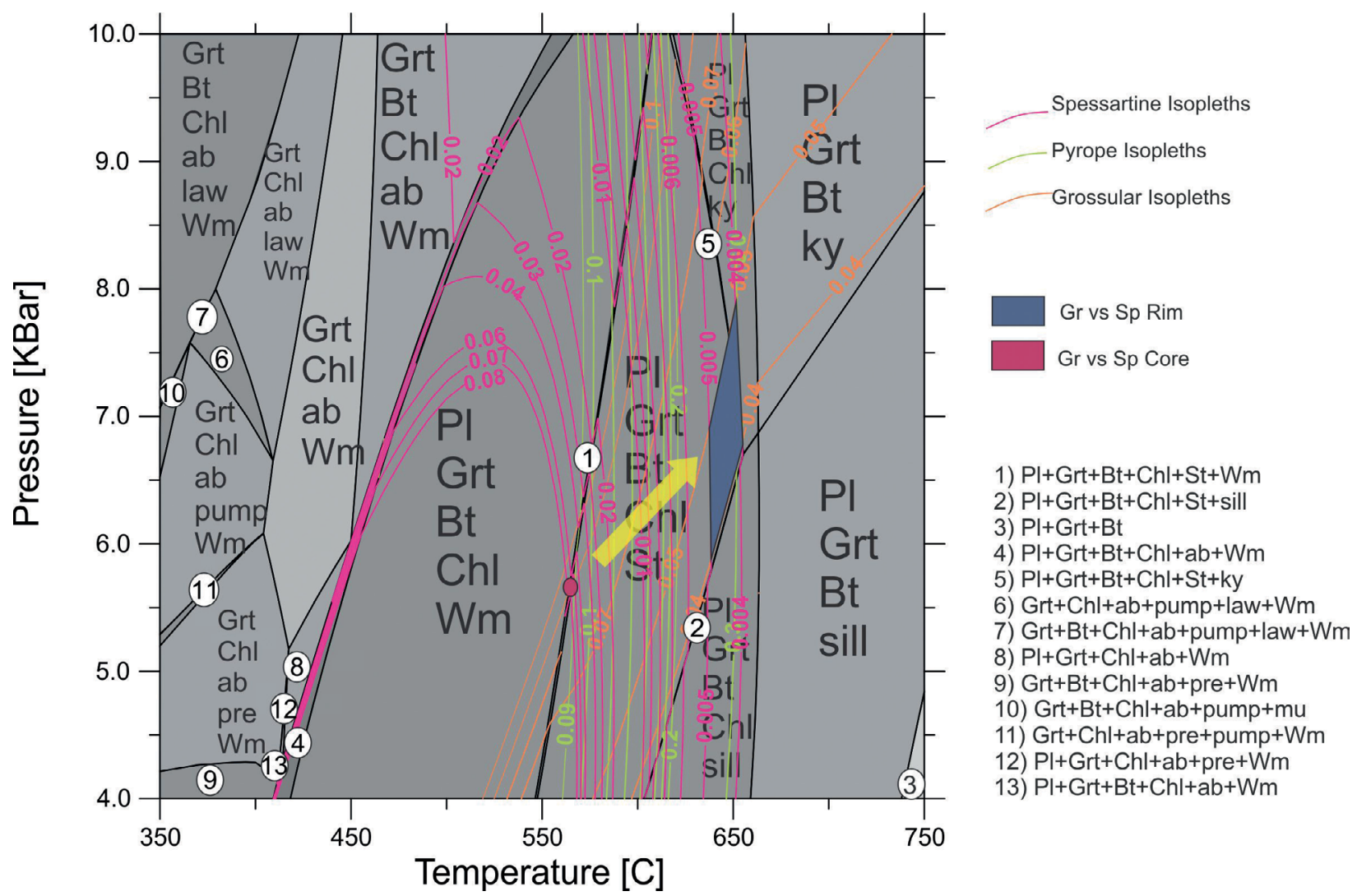

Figure 11. $\mathrm{P}-\mathrm{T}$ pseudosection modeling for sample ME07. Stable mineral assemblage is $\mathrm{Pl}+\mathrm{Grt}+\mathrm{Bt}+\mathrm{Chl}+\mathrm{Wm}+\mathrm{St}$. Isopleths intersection of garnets $\left(\mathrm{X}_{\mathrm{Gr}}\right.$ - orange lines and $\mathrm{X}_{\mathrm{Sp}}$ - pink lines) delimit rim mineral stability field highlighted by blue region. Pink circle is the intersection of core garnet endmembers. The proposed P-T trajectory is based on garnet composition (yellow arrow). $\mathrm{H}_{2} \mathrm{O}$ and quartz considered in excess. 


\section{Chemical method (CHIME)}

\section{Sample MEO7}

Monazite grains of ME07 mica schist are mainly from the foliated matrix. Grains are homogeneous, with no internal zoning in BSE images (Fig. 13A), mostly elongated, with 20 to $80 \mu \mathrm{m}$ diameter. Chemical analyses show content of $\mathrm{ThO}_{2}$ ranging from 2.81-6.67wt\%, $\mathrm{UO}_{2} 0.47-0.67 \mathrm{wt} \%, \mathrm{PbO} 0.09-$ $0.18 \mathrm{wt} \%$, and $\mathrm{Y}_{2} \mathrm{O}_{3} 0.005-0.925 \mathrm{wt} \%$ (complete data tables with monazite composition in Supplementary Table A6).

Twenty-one points were analyzed in ten monazite grains. ME07 mica schist displays Cambrian monazite ages
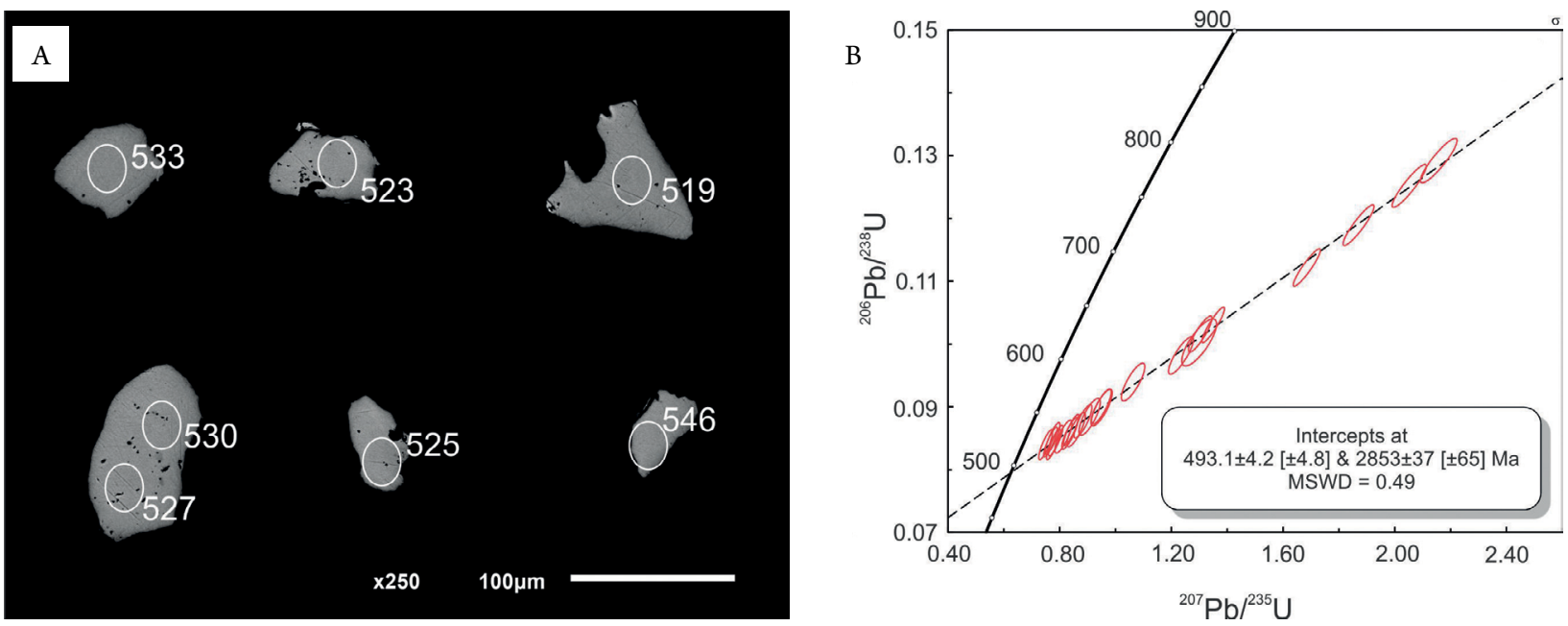

Figure 12. (A) Backscattered electron (BSE) images of dated monazite crystals from ME07 sample. Numbers are isotopic ages from monazite single analyses. (B) ${ }^{206} \mathrm{~Pb} /{ }^{238} \mathrm{U}$ vs. ${ }^{207} \mathrm{~Pb} /{ }^{238} \mathrm{U}$ LA-MC-ICP-MS Discordia diagram for ME07 monazite.

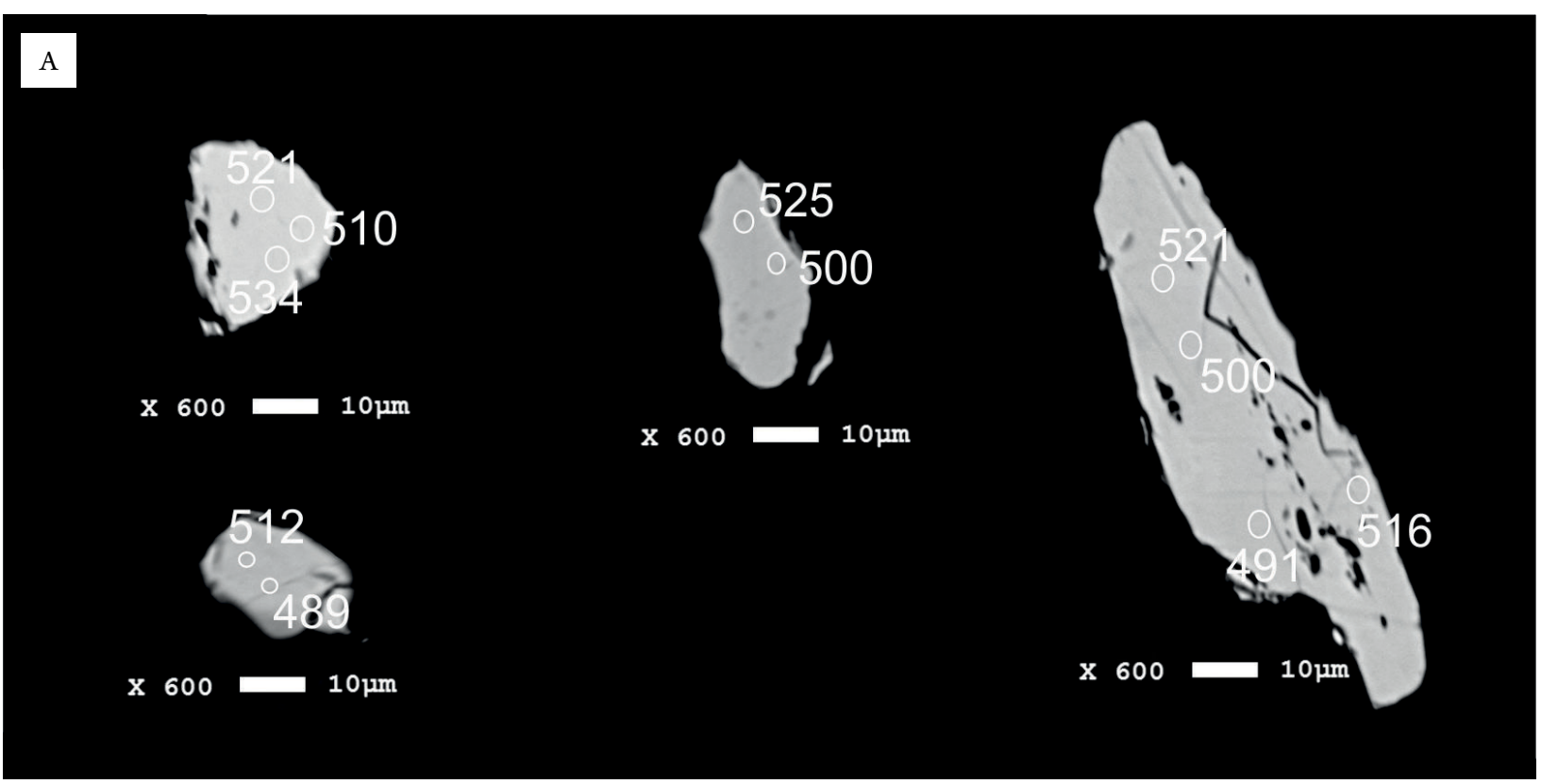

\section{B}
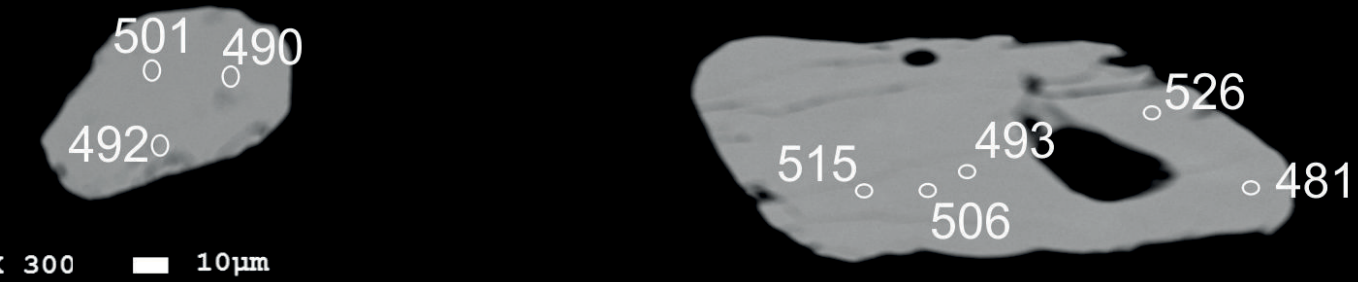

$\mathbf{x} 300$

[10 10m

Figure 13. BSE images of dated monazite in mica schists from Piranga region. Samples (A) ME07 and (B) ME08. Numbers are EMPA chemical ages from monazite single analyses. 
along a well-defined $\mathrm{ThO}_{2}{ }^{*}-\mathrm{PbO}$ isochron at $508 \pm 27 \mathrm{Ma}$ (Fig. 14A, Tab. 1).

\section{Sample ME08}

In the ME08 thin section, monazite grains vary from 60 to $200 \mu \mathrm{m}$ in diameter, allowing the analysis of up to 17 points on a single grain. Most of the analytical spots were in monazites from the foliated matrix, except for one included in garnet. Some grains are rounded, but most of them are elongated and subhedral. The zonation of core and rim is poorly defined in backscattered electron (BSE) images (Fig. 13B). Chemical analyses show content of $\mathrm{ThO}_{2}$ from 2.39-7.31wt\%, $\mathrm{UO}_{2} 0.38$ $0.88 \mathrm{wt} \%, \mathrm{PbO} 0.08-0.22 \mathrm{wt} \%$ and $\mathrm{Y}_{2} \mathrm{O}_{3} 0.26-0.84 \mathrm{wt} \%$ (complete tables in Supplementary Table A6).

Forty-four analyses in ten grains yielded $\mathrm{ThO}_{2}{ }^{*}-\mathrm{PbO}$ isochron at $498 \pm 25 \mathrm{Ma}$ for the ME08 sample (Fig. 14B, Tab. 1).

\section{DISCUSSION}

Two main results from this study are the correct stratigraphic position of the metapelitic sequence in Piranga region and the intense deformation of Brasiliano Orogeny on the SE border of QF.

\section{Maximum depositional age and provenance and new age constraints for Piranga schists}

Stratigraphy is based on $\mathrm{U}-\mathrm{Pb}$ detrital zircon geochronology from two staurolite-garnet mica schists. The rocks display similar geochronological pattern, yielding mostly Rhyacian (prominent peak at ca. 2,100 Ma) and minor Siderian and Archean ages. The youngest zircon population suggests maximum sedimentation age of $1,875 \pm 51 \mathrm{Ma}$. Paleoproterozoic grains dated around 2,500-2,000 Ma show both negative $\varepsilon \mathrm{Hf}_{(\mathrm{t})}=-10.7$ to -0.1 and positive $\varepsilon \mathrm{Hf}_{(\mathrm{t})}=0.0$ to +6.0 values, corresponding to crustal and juvenile sources. Granitoid suites were dated in Mineiro Belt, between 2,100 and 2,360 Ma (Seixas et al. 2013, Barbosa et al. 2015, Teixeira et al. 2015), which are possible sources for the sediments. Magmatic Rhyacian-Orosirian rocks from Mantiqueira Complex were dated at 2,180 to 2,040 Ma (Silva et al.2002, Noce et al. 2007, Novo 2013), whereas Juiz de Fora Complex yielded 2,130 to 2,080 Ma (Noce et al. 2007). Both complexes provided significant detrital sediment to the metasedimentary sequence. Grains older than 2,750 Ma present negative $\varepsilon \mathrm{Hf}_{(\mathrm{t})}=-5.6$ to -2.3 , representing sources formed with participation of crustal material, exemplified by Santa Bárbara (Fonseca 2017) and Bação complexes (Farina et al. 2015, Albert et al. 2016).

A comparison between the frequency histogram and probability curves for all available U-Pb data for the studied metapelites and Rio das Velhas Supergroup (Nunes 2016, Sousa 2016), Moeda Formation (Nunes 2016, Sousa 2016, Dopico et al. 2017), Sabará and Itacolomi Groups (Machado et al. 1996, Hartman et al. 2006, Jordt-Evangelista et al. 2015, Dopico et al. 2017, Duque 2018) provides insights into similarities and differences between the considered lithologies. Based on Figure 6, a prominent ca. 2,100 Ma peak for the samples studied herein is similar to Sabará and Itacolomi Groups, which are the youngest units of QF (Figs. 6A-E). We have noticed a similar pattern between our samples and those dated by Machado et al. (1996) and especially by Duque (2018) for the Itacolomi Group in its type-area, with a remarkable peak around 2,100 Ma and very little contribution from zircon of other ages.

Jordt-Evangelista et al. (2015) described similar features for Itacolomi Group lithologies, despite considerable Archean contribution (Fig. 6D). The metasedimentary rocks of Sabará Group display a large contribution from sources with age interval from 2,700 to 2,850 Ma, attributed to Rio das Velhas I and Mamona events (Lana et al. 2013), which are different from the geochronological pattern described here. However, since it is the maximum sedimentation age, we cannot exclude the hypothesis of correlation with Sabará Group, although the $1.9 \mathrm{Ga}$ age is not registered in this group (see Fig. 6E). Another correlation is with basal units of Espinhaço Supergroup, despite absence of $1.7 \mathrm{Ga}$ ages in our histograms. According to Chemale Jr. et al. (2012), the youngest ages obtained for detrital zircon grains of Bandeirinha and São João da Chapada Formations are around 1.7 to $1.8 \mathrm{Ga}$. Nevertheless, Espinhaço Supergroup has restricted occurrence in QF, preferentially in the northernmost region in the vicinity of Cambotas Range (Dutra 2017). Hence, in
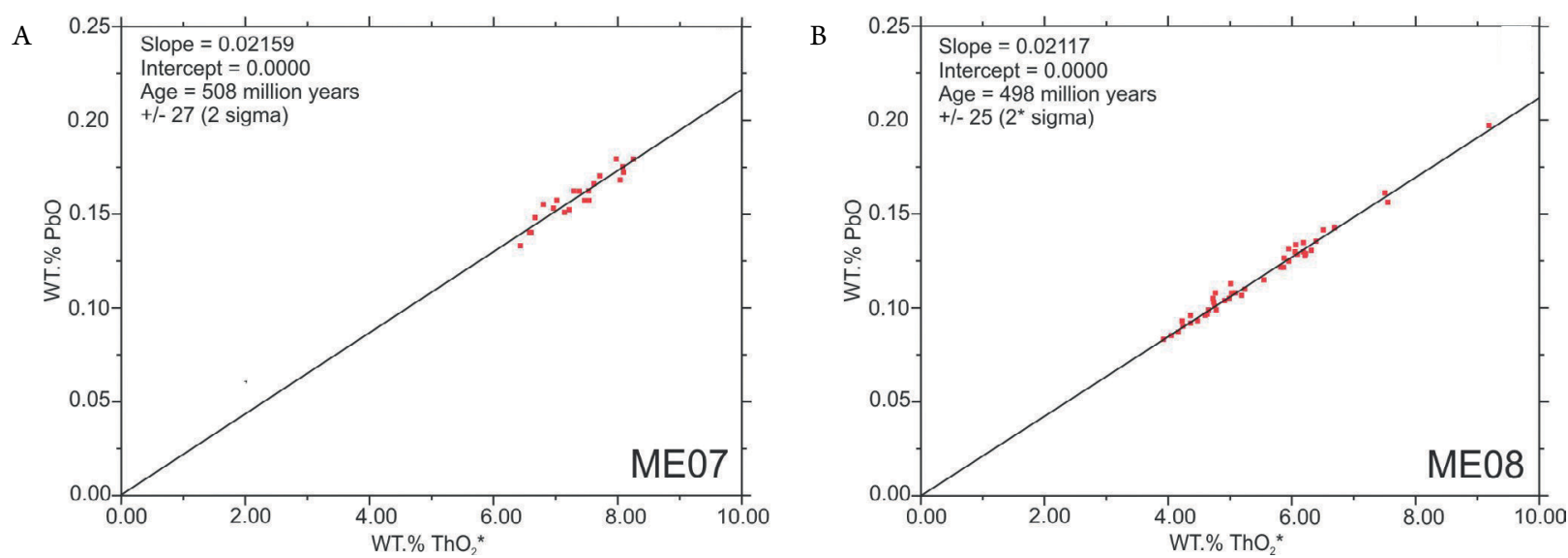

Figure 14. Th-U-Pb CHIME model ages in mica schists from Piranga region. (A) Total $\mathrm{PbO}_{\text {versus }} \mathrm{ThO}_{2}^{*}$ (wt.\%) plot for sample ME07. (B) Total $\mathrm{PbO}$ versus $\mathrm{ThO}_{2}{ }^{*}$ (wt.\%) plot for sample ME08. 
conclusion, Piranga schists correlate with the youngest units of QF (Sabará or Itacolomi Groups), without excluding, however, the Espinhaço Supergroup.

\section{Metamorphic ages and tectonic implications}

Current interpretations regarding time and intensity of metamorphic processes are based on multiple techniques, including average P-T geothermobarometry, pseudosection calculations, and both isotopic and chemical $\mathrm{U}-\mathrm{Pb}$ monazite dating. The three metapelite samples are pervasively foliated and contain garnet and staurolite porphyroblasts embedded in fine-to medium-coarse granolepidoblastic matrix. Both porphyroblastic minerals are syn- to post-kinematic with respect to the main, tightly folded foliation. All the analyzed garnet crystals show intense compositional zoning marked by $\mathrm{Fe}$ and $\mathrm{Mg}$ increase and $\mathrm{Mn}$ and Ca decrease toward the rims, implying prograde metamorphic conditions.

P-T estimates for the metamorphic peak use the average mode of THERMOCALC, which yields 630 to $650^{\circ} \mathrm{C}$ and around $7 \mathrm{kbar}$, medium-to-upper amphibolite facies. These P-T values are corroborated by pseudosections that indicate progressive metamorphic pattern. Homogeneous monazite grains in BSE images and with similar $\mathrm{Y}_{2} \mathrm{O}_{3}$ and $\mathrm{Ce}_{2} \mathrm{O}_{3}$ contents (see complete data tables in Supplementary Table A6) were dated by both isotopic and chemical methods. No evidence was found of multiple monazite generations in ME07 and ME08 samples. LA-MC-ICP-MS U-Pb geochronology resulted in $493 \pm 4 \mathrm{Ma}$, while CHIME ages are $498 \pm 25 \mathrm{Ma}$ and $508 \pm 27 \mathrm{Ma}$. Results show high correlation between the two methods, arguing for a Cambrian resetting or recrystallization. Monazite generation seems later than the medium-to-upper amphibolite facies metamorphic peak. The metamorphic peak age of this sequence is the most significant, but it remains unidentified. The metamorphic overprinting occurred during the Brasiliano Orogeny was considered, because the studied metasedimentary unit was deposited after the Rhyacian-Orosirian Orogeny (maximum sedimentation age at $1,875 \pm 51$ Ma with notable peak at ca. 2,100 Ma). U-Pb titanite and monazite dating from the southern SFC led Aguilar et al. (2017) to consider Paleoproterozoic metamorphism as a "long-lived event". Ages are in the intervals of 2,100-2,070 Ma and 2,070-2,050 Ma, considered syn-collisional (RhyacianOrosirian Event) and syn-extensional. On the other hand, Chemale Jr. et al. (1994) and Alkmim \& Marshak (1998) pointed out the role of the Brasiliano Orogeny in the QF architecture, based on geological evidence.

More recently, Cutts et al. (2018) demonstrated a strong Brasiliano overprint at 580-590 Ma on Mantiqueira Complex and Dom Silvério Group. This group outcrops East of Piranga region. Noticeably, fluid activity in the Cambrian is well registered by monazite resetting or recrystallization. Cambrian ages were reported on the surroundings of Piranga region and along the Araçuaí Orogen (Schmiedel 2015, Queiroga et al. 2016, 2018, Gonçalves 2018, Gonçalves et al. 2019). Fluid flow during low-to-medium grade metamorphism was related to the tectono-thermal collapse of Araçuaí Orogen (Alkmim et al. 2006). This final phase affected the QF border units as demonstrated in this study.

\section{CONCLUSIONS}

The geochronological and metamorphic dataset from this work allows the following conclusions:

- The metapelitic sequence composed of staurolite-garnet mica schists is correlative to the youngest units of QF (Sabará or Itacolomi Groups) or even to Espinhaço Supergroup, as supported by U-Pb geochronology, which contradicts previous positioning as Rio das Velhas Supergroup (Raposo 1991, 1998). This re-interpretation is based on the maximum sedimentation age $(1,875 \pm 51 \mathrm{Ma})$ of zircon from two metapelite samples, which is younger than previously considered. Both samples also display unimodal zircon pattern (peak at ca. 2,100 Ma);

- Considering the Paleoproterozoic sedimentation age, the main deformation associated with the metamorphic process was related to the Brasiliano Orogeny;

- Metamorphism reached amphibolite facies, with T and P values between $630-650^{\circ} \mathrm{C}$ and ca. $7 \mathrm{kbar}$;

- Isotopic and chemical monazite ages at around $500 \mathrm{Ma}$ point to recrystallization or resetting in the Cambrian;

- Metapelites from Piranga region are a repository of significant information concerning the evolution of QF in the Paleoproterozoic (depositional history) and Neoproterozoic-Early Paleozoic (metamorphism and deformation). U-Pb zircon and monazite geochronological data, thermobarometry, and pseudosection calculations are essential for decoding depositional timing and metamorphic evolution.

\section{ACKNOWLEDGMENTS}

This manuscript is part of the Master thesis by Yanne Queiroz at Programa de Pós-Graduação em Evolução Crustal e Recursos Naturais, from UFOP, Minas Gerais, Brazil. This work was financially supported by UFOP (Auxílio Pesquisador 09/2017, process number 23109.003268/201747) to G. Queiroga and by Fundação de Amparo à Pesquisa do Estado de São Paulo (FAPESP) project (process number 16/22627-3) to R. Moraes. We also thank the Microscopy and Microanalysis Laboratory (LMic) of UFOP, a member of the Fundação de Amparo à Pesquisa do Estado de Minas Gerais (FAPEMIG)-supported Microscopy and Microanalysis Network of Minas Gerais. Authors are also grateful to the anonymous reviewers and to Prof. Léo Hartmann for their important contributions to the manuscript improvement. G. Queiroga and C. Lana are fellows of the Brazilian Research Council (CNPq) and acknowledge the received support. Y. Queiroz is grateful to Coordenação de Aperfeiçoamento de Pessoal de Nível Superior (CAPES) for her scholarship. 


\section{ARTICLE INFORMATION}

Manuscript ID: 20180136. Received on: 12/12/2018. Approved on: 07/23/2019.

Y. S. Q. wrote the manuscript first draft and prepared all figures, tables and supplementary files. G. Q. improved the writing of all manuscript; this author is the $\mathrm{MsC}$ supervisor of Y. S. Q. R. M. helped with geothermobarometric calculations, petrological interpretations and discussions; this author is the $\mathrm{MsC}$ co-supervisor of Y. S. Q. V. M. T. F. and E. M. J. helped in the metamorphic modeling. H. J. E. contributed to petrographic analyses and mineral chemistry discussions. B. S. and M. P. C. performed mineral chemistry analyses at EPMA in Germany and Brazil, respectively. M. P. C. also contributed to the chemical monazite ages calculations. J. S. helped in field works and petrographic descriptions. M. M. also helped in field works, revised, and improved the manuscript. C. L. performed the LA-MC-ICP-MS analyses in zircon and monazite and assisted in data interpretation.

Competing interests: The authors declare no competing interests.

\section{REFERENCES}

Aguilar C., Alkmim F.F., Lana C., Farina F. 2017. Paleoproterozoic assembly of the São Francisco craton, SE Brazil: New insights from U-Pb titanite and monazite dating. Precambrian Research, 289:95-115.

Albert C., Farina F., Lana C., Stevens G., Storey C., Gerdes A., Dopico C.I.M. 2016. Archean crustal evolution in the southern São Francisco Craton, Brazil: constraints from $\mathrm{U}-\mathrm{Pb}, \mathrm{Lu}-\mathrm{Hf}$ and $\mathrm{O}$ isotope analyses. Lithos, 266-267:64-86. https://doi.org/10.1016/j.lithos.2016.09.029

Aleinikoff J.N., Schenk W.S., Plank M.O., Srogi L.A., Fanning C.M., Kamo S.L., Bosbyshell H. 2006. Deciphering igneous and metamorphic events in highgrade rocks of the Wilmington complex, Delaware: Morphology, cathodoluminescence and backscattered electron zoning, and SHRIMP $\mathrm{U}-\mathrm{Pb}$ geochronology of zircon and monazite. Geological Society of America Bulletin, 118(1-2):39-64. https://doi.org/10.1130/B25659.1

Alkmim F.F. 1987. Modelo deposicional para os metassedimentos da Serra de Ouro Branco, Quadrilátero Ferrífero, Minas Gerais. In: Simpósio sobre sistemas deposicionais do Pré-Cambriano, Ouro Preto. Boletim SBG-MG. v. 6 , p. $47-68$.

Alkmim F.F. \& Marshak S. 1998. The Transamazonian orogeny in the Quadrilátero Ferrífero, Minas Gerais, Brazil: Paleoproterozoic collision and collapse in the Southern São Francisco Craton region. Precambrian Research, 90(1-2):29-58.

Alkmim F.F. \& Martins-Neto M.A. 2012. Proterozoic first-order sedimentary sequences of the São Francisco craton, eastern Brazil. Marine and Petroleum Geology, 33(1):127-139.

Alkmim F.F. \& Teixeira W. 2017. The Paleoproterozoic Mineiro Belt and the Quadrilátero Ferrífero. In: Heilbron M., Cordani U., Alkmim F. (Eds.). São Francisco Craton, Eastern Brazil. Regional Geology Reviews. New York, Springer, p. 71-94.

Alkmim F.F., Marshak S., Pedrosa-Soares A.C., Peres G.G., Cruz S., Whittington A. 2006. Kinematic evolution of the Araçuaí-West Congo orogen in Brazil and Africa: Nutcracker tectonics during the Neoproterozoic assembly of Gondwana. Precambrian Research, 149(1-2):43-64.

Almeida F.F.M. 1977. O Cráton do São Francisco. Revista Brasileira de Geociências, 7(4):349-364.

Ávila C.A., Teixeira W., Bongiolo E.M., Dussin I.A., Vieira T.A.T. 2014. Rhyacian evolution of subvolcanic and metasedimentary rocks of the Southern segment of the Mineiro belt, São Francisco Craton, Brazil. Precambrian Research, 243:221-251. https://doi.org/10.1016/j. precamres.2013.12.028

Babinski M., Chemale Jr. F., Van Schmus W.R. 1995. The Pb/ $\mathrm{Pb}$ age of the Minas Supergroup carbonate rocks, Quadrilátero Ferrífero, Brazil. Precambrian Research, 72(3-4):235-245. https://doi. org/10.1016/0301-9268(94)00091-5

Baltazar O.F. \& Pedreira A.J. 1998. Associações de litofácies. In: Zucchetti M. \& Baltazar O.F. (Eds.). Projeto Rio das Velhas: Texto Explicativo do Mapa Geológico Integrado, escala 1:100.000. 2. ed. Belo Horizonte, DNPM/ CPRM, p. 43-47.

Barbosa A.L.M. 1968. Contribuições recentes à geologia do Quadrilátero Ferrífero. SBG-MG. Belo Horizonte, UFMG, Departamento de Geologia, Instituto de Geociências, $44 \mathrm{p}$.

Barbosa J.S.F. \& Sabaté P. 2004. Archean and Paleoproterozoic crust of the São Francisco Craton, Bahia, Brazil: geodynamic features. Precambrian Research, 133:1-27.
Barbosa N.S., Teixeira W., Ávila C.A., Montecinos P.M., Bongiolo E.M. 2015. 2.17-2.10 Ga plutonic episodes in the Mineiro belt, São Francisco Craton, Brazil: U-Pb ages, geochemical constraints and tectonics. Precambrian Research, 270:204-225. https://doi.org/10.1016/j.precamres.2015.09.010

Belo de Oliveira O. A. \& Teixeira W. 1990. Evidências de uma tectônica tangencial proterozóica no Quadrilátero Ferrífero. In: 36 Congresso Brasileiro de Geologia, Natal. Abstracts, p. 2589-2604.

Blichert-Toft J. \& Puchtel I.S. 2010. Depleted mantle sources through time: evidence from $\mathrm{Lu}-\mathrm{Hf}$ and $\mathrm{Sm}-\mathrm{Nd}$ isotope systematics of Archean komatiites. Earth and Planetary Science Letters, 297(3):598-606. http://doi. org/10.1016/j.epsl.2010.07.012

Bouvier A., Vervoort J.D., Patchett P.J. 2008. The Lu-Hf and Sm-Nd isotopic composition of CHUR: constraints from unequilibrated chondrites and implications for the bulk composition of terrestrial planets. Earth and Planetary Science Letters, 273(1-2):48-57. http://dx.doi.org/10.1016/j. epsl.2008.06.010

Brueckner H., Cunningham W.D., Alkmim F.F., Marshak S. 2000. Tectonic implications of Precambrian Sm-Nd dates from the southern São Francisco craton and adjacent Araçuaí and Ribeira belts, Brazil. Precambrian Research, 99(3-4):255-269. https://doi.org/10.1016/S0301-9268(99)00065-0

Cabral A.R., Zeh A., Koglin N., Gomes Jr. A.A.S., Viana D.J., Lehmann D. 2012. Dating the Itabira iron formation, Quadrilátero Ferrifero of Minas Gerais, Brazil, at 2.65 Ga: Depositional U-Pb age of zircon from a metavolcanic layer. Precambrian Research, 204-205:40-45. http://dx.doi. org/10.1016/j.precamres.2012.02.006

Canuto J.R. 2010. Estratigrafia de seqüências em bacias sedimentares de diferentes idades e estilos tectônicos. Revista Brasileira de Geociências, 40(4):537-549.

Carneiro M.A., Carvalho Jr. I.M., Teixeira, W. 1998. Petrologia, geoquímica e geocronologia dos diques máficos do Complexo Bonfim Setentrional (Quadrilátero Ferrífero) e suas implicações na evolução crustal do Cráton São Francisco Meridional. Revista Brasileira de Geociências, 28(1):29-44.

Chemale Jr. F., Dussin I.A., Alkmim F.F., Martins M.S., Queiroga G., Armstrong R., Santos M.N. 2012. Unravelling a Proterozoic basin history through detrital zircon geochronology: the case of the Espinhaço Supergroup, Minas Gerais, Brazil. Gondwana Research, 22:200-206. http:// dx.doi.org/10.1016/j.gr.2011.08.016

Chemale Jr. F., Rosière C.A., Endo I. 1994. The tectonic evolution of the Quadrilátero Ferrífero, Minas Gerais, Brazil. Precambrian Research, 65(14):25-54. https://doi.org/10.1016/0301-9268(94)90098-1

Coggon R. \& Holland T.J.B. 2002. Mixing properties of phengitic micas and revised garnet-phengite thermobarometers. Journal of Metamorphic Geology, 20(7):683-696. https://doi.org/10.1046/j.1525-1314.2002.00395.x

Cutts K., Lana C., Alkmim F., Farina F., Moreira H., Coelho V. 2019. Metamorphism and exhumation of basement gneiss domes in the Quadrilátero Ferrífero: Two stage dome-and-keel evolution? Geoscience Frontiers, 10(5):1765-1787. https://doi.org/10.1016/j.gsf.2019.02.009

Cutts K., Lana C., Alkmim F.F., Peres G.G. 2018. Metamorphic imprints on units of the southern Araçuaí Belt, SE Brazil: The history of superimposed Transamazonian and Brasiliano orogenesis. Gondwana Research, 58:211234. https://doi.org/10.1016/j.gr.2018.02.016

Dardenne M.A. 2000. The Brasília fold belt. In: Cordani U.G., Milani E.J., Thomaz Filho A., Campos D.A. (Eds.). Tectonic Evolution of South America. 31st International Geological Congress, Rio de Janeiro. p. 231-236. 
De Capitani C. \& Petrakakis K. 2010. The computation of equilibrium assemblage diagrams with Theriak/Domino software. American Mineralogist, 95(7):1006-1016. https://doi.org/10.2138/am.2010.3354

Donovan J.J., Hanchar J.M., Picolli P.M., Schrier M.D., Boatner L.A., Jarosewich E. 2003. A re-examination of the rare-earth element orthophosphate standards in use for electron-microprobe analysis. Canadian Mineralogist, 41(1):221-232. http://doi.org/10.2113/ gscanmin.41.1.221

Dopico C.I.M., Lana C.C., Moreira H.S., Cassino L.F., Alkmim F.F 2017. U-Pb ages and Hf-isotope data of detrital zircons from the late Neoarchean-Paleoproterozoic Minas Basin, SE Brazil. Precambrian Research, 291:143-161.

Dorr II J.V.N. 1964. Supergene iron ores of Minas Gerais, Brazil. Economic Geology, 59(7):1203-1240.

Dorr II J.V.N. 1969. Physiographic, stratigraphic and structural development of the Quadrilátero Ferrífero, Minas Gerais, Brazil. U.S. Geological Survey Professional Paper, 641-A, 110 p.

Duque T.R.F. 2018. O Grupo Itacolomi em sua área-tipo: estratigrafia, estrutura e significado tectônico. MS Dissertation, Departamento de Geologia, Universidade Federal de Ouro Preto, Ouro Preto, 102p.

Dutra L.F. 2017. Caracterização geocronológica U-Th-Pb de zircões detríticos na porção nordeste do sinclinal Gandarela - implicações para evolução sedimentar e geotectônica do Quadrilátero Ferrífero. MS Dissertation, Departamento de Geologia, Universidade Federal de Ouro Preto, Ouro Preto, 100p.

Farina F., Albert C., Dopico C.M., Aguilar Gil C., Moreira H., Hippertt J., Cutts K., Alkmim F., Lana C. 2016. The Archean-Paleoproterozoic evolution of the Quadrilátero Ferrífero (Brazil): current models and open questions. Journal of South American Earth Sciences, 68:4-21. http://dx.doi. org/10.1016/j.jsames.2015.10.015

Farina F., Albert C., Lana C. 2015. The Neoarchean transition between medium and high-K granitoids: clues from the Southern São Francisco Craton (Brazil). Precambrian Research, 266:375-394. http://dx.doi. org/10.1016/j.precamres.2015.05.038

Fonseca G.M. 2017. Petrogênese de rochas metaultramáficas do Quadrilátero Ferrífero e adjacências e geocronologia de terrenos associados. $\mathrm{PhD}$ Thesis, Departamento de Geologia, Universidade Federal de Ouro Preto, Ouro Preto, $108 \mathrm{p}$.

Gerdes A. \& Zeh A. 2006. Combined U-Pb and Hf isotope LA-(MC) ICP-MS analyses of detrital zircons: comparison with SHRIMP and new constraints for the provenance and age of an Armorican metasediment in Central Germany. Earth and Planetary Science Letters, 249(1-2):47-61. https://doi.org/10.1016/j.epsl.2006.06.039

Gonçalves G.O. 2018. Geocronologia U-Pb de minerais hidrotermais: Materiais de referência, métodos e aplicações. $\mathrm{PhD}$ Thesis, Departamento de Geologia, Universidade Federal de Ouro Preto, Ouro Preto, 326p.

Gonçalves G.O., Lana C., Buick I.S., Alkmim F.F., Scholz R., Queiroga G. 2019. Twenty million years of post-orogenic fluid production and hydrothermal mineralization across the external Araçuaí orogen and adjacent São Francisco craton, SE Brazil. Lithos, 342-343:557-572. http:// dx.doi.org/10.1016/j.lithos.2019.04.022

Gonçalves G.O., Lana C., Scholz R., Buick I.S., Gerdes A., Kamo S.L., Corfu F., Rubatto D., Wiedenbeck M., Nalini Jr. H.A., Oliveira L.C.A. 2018. The Diamantina monazite: a new low-Th reference material for microanalysis. Geostandards and Geoanalytical Research, 42(1):25-47. https://doi. org/10.1111/ggr.12192

Hartmann L.A., Endo I., Suita M.T.F., Santos J.O.S., Frantz J.C., Carneiro M.A., McNaughton N.J., Barley M.E. 2006. Provenance and age delimitation of Quadrilátero Ferrífero sandstones based on zircon U-Pb isotopes. Journal of South American Earth Sciences, 20:273-285. https://doi.org/10.1016/j. jsames.2005.07.015

Heilbron M., Duarte B.P., Valeriano C.M., Simonetti A., Machado N., Nogueira J.R. 2010. Evolution of reworked Paleoproterozoic basement rocks within the Ribeira belt (Neoproterozoic), SE-Brazil, based on U-Pb geochronology: Implications for paleogeographic reconstructions of the São Francisco-Congo paleocontinet. Precambrian Research, 178(1):136148. http://dx.doi.org/10.1016/j.precamres.2010.02.002

Herz N. 1978. Metamorphic Rocks of the Quadrilátero Ferrifero. United States Geological Survey, Minas Gerais, Brazil, Professional Paper, 641-C, 81p.
Holland T.J.B. \& Powell R. 1998. An internally consistent thermodynamic data set for phases of petrological interest. Journal of Metamorphic Geology, 16(3):309-343. https://doi.org/10.1111/j.1525-1314.1998.00140.x

Holland T.J.B. \& Powell R. 2003. Activity-composition relations for phases in petrological calculations: An asymmetric multicomponent formulation. Contributions to Mineralogy and Petrology, 145(4):492-501. http://dx.doi. org/10.1007/s00410-003-0464-z

Jackson S.E., Pearson N.J., Griffin W.L., Belousova E.A. 2004. The application of laser ablation-inductively coupled plasma-mass spectrometry to in-situ U-Pb zircon geochronology. Chemical Geology, 21 1 (1-2):47-69. https://doi.org/10.1016/j.chemgeo.2004.06.017

Jarosewich E. \& Boatner L.A. 1991. Rare-earth element reference samples for electron microprobe analysis. Geostandards Newsletter, 15(2):397-399. https://doi.org/10.1111/j.1751-908X.1991.tb00115.x

Jordt-Evangelista H., Alkmim F.F., Marshak S. 1992. Metamorfismo progressivo e a ocorrência de três polimorfos de $\mathrm{Al}_{2} \mathrm{SiO}_{5}$ (cianita, andaluzita e sillimanita) na Formacão Sabará em Ibirité, Quadrilátero Ferrífero, MG. Revista da Escola de Minas, 45:157-160.

Jordt-Evangelista H., Alvarenga J.P.M., Lana C. 2015. Petrography and geochronology of the Furquim Quartzite, an eastern extension of the Itacolomi Group (Quadrilátero Ferrífero, Minas Gerais). Revista Escola de Minas, 68(4):393-399.

Jordt-Evangelista H. \& Peres G.G. 1997. O maciço sienítico de Piranga, Minas Gerais. In: 9o Simpósio de Geologia de Minas Gerais. Ouro Preto. Boletim SBG-MG, v. 14, p. 110-112.

Jordt-Evangelista H., Peres G.G., Macambira M.J.B. 2000. Pb/Pb single zircon dating of Paleoproterozoic calc-alkaline/alkaline magmatism in the southeastern São Francisco Craton region, Brazil. Revista Brasileira de Geociências, 30 (1):174-176.

Koglin N., Zeh A., Cabral A.R., Gomes Jr. A.A.S., Correa Neto A.V., Brunetto W.J., Galbiatti H. 2014. Depositional age and sediment source of the auriferous Moeda Formation, Quadrilátero Ferrífero of Minas Gerais Brazil: new constraints from $\mathrm{U}-\mathrm{Pb}-\mathrm{Hf}$ isotopes in zircon and xenotime. Precambrian Research, 255:96-108. http://dx.doi.org/10.1016/j. precamres.2014.09.010

Lana C., Alkmim F.F., Armstrong R., Scholz R., Romano R., Nalini Jr. H.A 2013. The ancestry and magmatic evolution of Archean TTG rocks of the Quadrilátero Ferrífero province, southeast Brazil. Precambrian Research, 231:157-173. http://dx.doi.org/10.1016/j.precamres.2013.03.008

Lana C., Farina F., Gerdes A., Alkmim A., Gonçalves G.O., Jardim A.C. 2017. Characterization of zircon reference materials via high precision U-Pb LA-MC-ICP-MS. Journal of Analytical Atomic Spectrometry, 32:2011-2023. http://dx.doi.org/10.1039/C7JA00167C

Lobato L.M., Ribeiro-Rodrigues L.C., Zucchetti M., Noce C.M., Baltazar O. da Silva L.C., Pinto C.P. 2001. Brazil's premier gold province. Part I: The tectonic, Magmatic, and structural setting of the Archean Rio das Velhas greenstone belt, Quadrilátero Ferrífero. Mineralium Deposita, 36(3-4):228248. https://doi.org/10.1007/s001260100179

Ludwig K.R. 2003. User's Manual for Isoplot/Ex, Version 3.0, A geochronological tool kit for Microsoft Excel. Berkeley, Berkeley Geochronology Center Special Publication. v. 4. 73p.

Machado N. \& Carneiro M. 1992. U-Pb evidence of late Archean tectonothermal activity on the southern São Francisco shield, Brazil. Canadian Journal of Earth Sciences, 29(11):2341-2346. http://dx.doi.org/10.1139/ e92-182

Machado N., Noce C.M., Ladeira E.A., Belo de Oliveira O.A. 1992 $\mathrm{U}-\mathrm{Pb}$ geochronology of the Archean magmatism and Proterozoic metamorphism in the Quadrilátero Ferrífero, southern São Francisco Craton, Brazil. Geological Society of America Bulletin, 104(9):1221-1227. https://doi.org/10.1130/0016-7606(1992)104\%3C1221:UPGOAM\%3 E2.3.CO;2

Machado N., Schrank A., Noce C.M., Gauthier G. 1996. Ages of detrita zircon from Archean-Paleoproterozoic sequences: implications for Greenstone Belt setting evolution of a Transamazonian foreland basin in Quadrilátero Ferrífero, southeast Brazil. Earth and Planetary Science Letters, 141(1-4):259-276. https://doi.org/10.1016/0012-821X(96)00054-4

Mahar E.M., Baker J.M., Powell R., Holland T.J.B., Howell N. 1997. The effect of $\mathrm{Mn}$ on mineral stability in metapelites. Journal of Metamorphic Geology, 15(2):223-238. https://doi.org/10.1111/j.1525-1314.1997.00011.x 
Marshak S., Alkmim F.F., Jordt-Evangelista H. 1992. Proterozoic crustal extension and the generation of dome-and-keel structure in an Archean granite-greenstone terrane. Nature, 357:491-493.

Mendes M.C.O., Lobato L.M., Suckau V., Lana C. 2014. In situ LA-ICPMS $\mathrm{U}-\mathrm{Pb}$ dating of detrital zircons from the Cercadinho Formation, Minas Supergroup. Geologia USP - Série Científica, 14(1):55-68.

Moreira H.S., Lana C.C., Nalini Jr. H.A. 2016. The detrital zircon record of an Archaean convergent basin in the Southern São Francisco Craton, Brazil. Precambrian Research, 275:84-99.

Noce C.M. 1995. Geocronologia dos eventos magmáticos, sedimentares e metamórficos na região do Quadrilátero Ferrífero, Minas Gerais. $\mathrm{PhD}$ Thesis, Universidade de São Paulo, São Paulo, 129p.

Noce C.M., Machado, N., Teixeira W. 1998. U-Pb geochronology of gneisses and granitoids in the Quadrilátero Ferrífero (southern São Francisco Craton): age constraints for Archean and Paleoproterozoic magmatism and metamorphism. Revista Brasileira de Geociências, 28:95-102.

Noce C.M., Pedrosa-Soares A.C., Silva L.C., Alkmim F.F. 2007. O embasamento Arqueano e Paleoproterozóico do Orógeno Araçuaí. Geonomos, 15(1):17-23. https://doi.org/10.18285/geonomos. v15i1.104

Noce C., Zuccheti M., Baltazar O., Armstrong R., Dantas E., Renger F., Lobato L. 2005. Age of felsic volcanism and the role of ancient continental crust in the evolution of the Neoarchean Rio das Velhas Greenstone belt (Quadrilátero Ferrífero, Brazil): U-Pb zircon dating of volcanoclastic graywackes. Precambrian Research, 141(1):67-82. http://dx.doi. org/10.1016/j.precamres.2005.08.002

Novo T.A. 2013. Caracterização do Complexo Pocrane, magmatismo básico Mesoproterozóico e unidades Neoproterozóicas do sistema Araçuaí-Ribeira, com ênfase em geocronologia U-Pb (SHRIMP e LA-ICP-MS). PhD Thesis, Instituto de Geociências, Universidade Federal de Minas Gerais, Belo Horizonte, 193p

Nunes F.S. 2016. Contribuição à estratigrafia e geocronologia U-Pb de zircões detríticos da Formação Moeda (Grupo Caraça, Supergrupo Minas) na Serra do Caraça, Quadrilátero Ferrífero, Minas Gerais. MS Dissertation, Departamento de Geologia, Universidade Federal de Ouro Preto, Ouro Preto, 77p.

Oliveira E.P., McNaughton N.J., Armstrong R. 2010. Mesoarchaean to Palaeoproterozoic growth of the northern segment of the Itabuna-SalvadorCuraçá Orogen, São Francisco Craton, Brazil. In: Kusky T.M., Zhai M.G., Xiao W. (Eds.). The Evolving Continents: Understanding Processes of Continental Growth, v. 338, p. 263-286. London, Geological Society of London Special.

Pedrosa-Soares A.C., Noce C.M., Alkmim F.F., Silva L.C., Babinski M., Cordani U., Castañeda C. 2007. Orógeno Araçuaí: síntese do conhecimento 30 anos após Almeida 1977. Geonomos, 15(1):1-16. https://doi. org/10.18285/geonomos.v15i1.103

Pedrosa-Soares A.C., Noce C.M., Wiedemann C.M., Pinto C.P. 2001. The Araçuaí-West Congo orogen in Brazil: an overview of a confined orogen formed during Gondwanaland assembly. Precambrian Research, 110:307-323.

Pimentel M.M., Fuck R.A., Gioia D.M.C.L. 2000. The Neoproterozoic Goiás Magmatic Arc, Central Brazil: A review and new Sm-Nd isotopic data. Revista Brasileira de Geociências, 30(1):35-39.

Powell R. \& Holland T.J.B. 1988. An internally consistent thermodynamic dataset with uncertainties and correlations: 3: application methods, worked examples and a computer program. Journal of Metamorphic Geology, 6(2):173-204. https://doi.org/10.1111/j.1525-1314.1988. tb00415.x

Powell R. \& Holland T.J.B. 1994. Optimal geothermometry and geobarometry. Journal of Metamorphic Geology, 79(1-2):120-133.

Queiroga G.N., Batista J.P.F., Hartmann L.A., Lana C.C., Jordt-Evangelista H., Santos J.O.S., Castro M.P., Alkmim, A.R. 2018. Metasomatic evolution on Barroca chloritites, Quadrilátero Ferrífero. In: 49 Congresso Brasileiro de Geologia, Rio de Janeiro. Resumos.

Queiroga G.N., Schulz B., Martins M.S., Castro M.P., Jordt-Evangelista H., Silva A.L. 2016. Thermobarometry and electron-microprobe Th-U-Pb monazite dating in garnet metapelites from the Capelinha Formation, Araçuaí Orogen, Brazil. Revista da Escola de Minas, 69(1):33-44.
Raposo F.O. 1991. Estratigrafia, Petrografia e Petrologia. In: Raposo F.O. (Ed.). Rio Espera, Folha SF.23-X-B-IV, Estado de Minas Gerais. Brasília, DNPM-CPRM (Programa Levantamentos Geológicos Básicos do Brasil — PLGB), p. 27-88.

Raposo F.O. 1998. Geologia da Folha Ponte Nova (SF.23-X-B), leste de Minas Gerais, Brasil. In: 40 Congresso Brasileiro Geologia, Belo Horizonte. Anais, p. 30 .

Renger F.E., Noce C.M., Romano A.W., Machado N. 1995. Evolução sedimentar do Supergrupo Minas: $500 \mathrm{Ma}$ de registro geológico no Quadrilátero Ferrífero, Minas. Geonomos, 2(1):1-11. http://doi. org/10.18285/geonomos.v2i1.227

Romano R., Lana C., Alkmim F.F., Stevens G.S., Armstrong R. 2013. Stabilization of the southern portion of the São Francisco Craton, SE Brazil, through a long-lived period of potassic magmatism. Precambrian Research, 224:143-159. http://doi.org/10.1016/j.precamres.2012.09.002

Santos M.M., Lana C., Scholz R., Buick I., Schmitz M.D., Kamo S.L., Gerdes A., Corfu F., Tapster S., Lancaster P., Storey C.D., Basei M.A.S., Tohver E., Alkmim A., Nalini H., Krambrock K., Fantini C., Wiedenbeck M. 2017. A new appraisal of Sri Lankan BB zircon as a reference material for LA-ICPMS U-Pb geochronology and $\mathrm{Lu}-\mathrm{Hf}$ isotope tracing. Geostandards and Geoanalytical Research, 41(3):335-358. https://doi.org/10.1111/ggr.12167

Schrank A. \& Machado N. 1996a. Idades U-Pb em monazitas e zircões das minas de Morro Velho e Passagem de Mariana - Quadrilátero Ferrífero (MG). In: 39० Congresso Brasileiro de Geologia, Salvador. Abstracts, p. 470-472.

Schrank A. \& Machado N. 1996b. Idades U-Pb em monazitas e zircões do distrito aurífero de Caeté, da Mina de Cuiabá e do Depósito de Carrapato - Quadrilátero Ferrífero (MG). In: 39 Congresso Brasileiro de Geologia, Salvador. Abstracts, p. 473-475.

Schmiedel J. 2015. Monazite dating and geothermobarometry in metamorphic rocks of Piranga region, Iron Quadrangle, Minas Gerais, Brazil.MS Dissertation, Technische Universität Bergakademie Freiberg, Freiberg, 111p.

Schorscher J.H.D. 1992. Arcabouço petrográfico e evolução crustal dos terrenos pré-cambrianos do sudeste de Minas Gerais: Quadrilátero Ferrífero, Espinhaço Meridional, e domos granitoides-gnáissicos adjacentes. $\mathrm{PhD}$ Thesis, Universidade de São Paulo, São Paulo, 393p.

Schulz B., Brätz H., Bombach K., Krenn E. 2007. In situ Th-Pb dating of monazite by $266 \mathrm{~nm}$ laser ablation and ICP-MS with a single collector, and its control by EMP analysis. Zeitschrift für Angewandte Geologie, 35:377-392.

Schulz B. \& Schüssler U. 2013. Electron-microprobe Th-U-Pb monazite dating in Early-Paleozoic high-grade gneisses as a completion of U-Pb isotopic ages (Wilson Terrane, Antarctica). Lithos, 175-176:178-192. http://dx.doi.org/10.1016/j.lithos.2013.05.008

Seixas L.A.R., Bardintzeff J.M., Stevenson R., Bonin B. 2013. Petrology of the high- Mg tonalites and dioritic enclaves of the ca. $2130 \mathrm{Ma}$ Alto Maranhão suite: evidence for a major juvenile crustal addition event during the Rhyacian orogenesis, Mineiro Belt, southeast Brazil. Precambrian Research, 238:18-41. https://doi.org/10.1016/j.precamres.2013.09.015

Silva D.F.S. 2014. Petrogênese e geocronologia do Sienito Piranga, MG. Monography, Departamento de Geologia, Universidade Federal de Ouro Preto, Ouro Preto, 127p.

Silva L.C., Armstrong R., Noce C.M., Carneiro M., Pimentel M., PedrosaSoares A.C., Leite C., Vieira V.S., Silva M., Paes V., Cardoso-Filho J. 2002. Reavaliação da evolução geológica em terrenos pré-cambrianos brasileiros com base em novo dados U-Pb SHRIMP, parte II: Orógeno Araçuaí, Cinturão Móvel Mineiro e Cráton São Francisco Meridional. Revista Brasileira de Geociências, 32(4):513-528.

Söderlund U., Patchett J.P., Vervoort J.D., Isachsen C.E. 2004. The ${ }^{176} \mathrm{Lu}$ decay constant determined by $\mathrm{Lu}-\mathrm{Hf}$ and $\mathrm{U}-\mathrm{Pb}$ isotope systematics of Precambrian mafic intrusions. Earth and Planetary Science Letters, 219(34):311-324. https://doi.org/10.1016/S0012-821X(04)00012-3

Sousa F.A. 2016. Análise cronoestratigráfica das sequências sedimentares das bacias Minas e Rio das Velhas no Anticlinal de Mariana. Monography. Departamento de Geologia, Universidade Federal de Ouro Preto, Ouro Preto, 62p.

Suzuki K. \& Adachi M. 1991. Precambrian provenance and Silurian metamorphism of the Tsubonosawa paragneiss in the South Kitakami terrane, northeast Japan, revealed by the chemical Th-U-total $\mathrm{Pb}$ isochron ages of monazite, zircon and xenotime. Geochemical Journal, 25 (5):357-376. https://doi.org/10.2343/geochemj.25.357 
Suzuki K. \& Adachi M. 1994. Middle Precambrian detrital monazite and zircon from the Hida gneiss on Oki-Dogo Island, Japan: their origin and implication for the correlation of the basement of Southwest Japan and Korea. Tectonophysics, 235:277-292.

Suzuki K., Adachi M., Kajizuka I. 1994. Electron microprobe observations of $\mathrm{Pb}$ diffusion in metamorphosed detrital monazites. Earth and Planetary Science Letters, 128(3-4):391-405. https://doi.org/10.1016/0012-821X(94)90158-9

Teixeira W. 1985. Esboço da evolução geotectônica da parte sul do cráton do São Francisco: uma interpretação com base nos dados Rb-Sr, K-Ar, Pb$\mathrm{Pb}$ e traços de fissão. In: $3^{\circ}$ Simpósio de Geologia de Minas Gerais, Belo Horizonte. Boletim SBG-MG), v. 3, p. 28-44.

Teixeira W., Ávila C.A., Dussin I.A., Corrêa Neto A.V., Bongiolo E.M., Santos J.O., Barbosa N.S. 2015. A juvenile accretion episode $(2.35-2.32 \mathrm{Ga})$ in the Mineiro Belt and its role to the Minas accretionary orogeny: zircon $\mathrm{U}-\mathrm{Pb}-$ Hf and geochemical evidences. Precambrian Research, 256:148-169. http:// dx.doi.org/10.1016/j.precamres.2014.11.009

Teixeira W. \& Figueiredo M.C.H. 1991. An outline of early Proterozoic crustal evolution in the São Francisco region, Brazil: A review. Precambrian Research, 53(1-2):1-22. https://doi.org/10.1016/0301-9268(91)90003-S

Valeriano C.M., Dardenne M.A., Fonseca M.A., Simões L.S.A., Seer H.J. 2004. A evolução tectônica da Faixa Brasília. In: Mantesso-Neto V., Bartorelli A., Carneiro C.D.R., Brito Neves B.B. (Eds.). Geologia do Continente Sul-Americano: evolução e obra de Fernando Flávio Marques de Almeida. São Paulo, Beca, p. 575-593.
Van Achterbergh E., Ryan C.G., Jackson S.E., Griffin W.L. 2001. Data reduction software for LA-ICP-MS: appendix. In: Sylvester P.J. (Ed.) Laser Ablation-ICP Mass Spectrometry in the Earth Sciences: Principles and Applications. Ottawa, Mineralogical Association of Canada (MAC), Short Course Series, v. 29, p. 239-243.

White R.W., Pomroy N.E., Powell R. 2005. An in-situ metatexitediatexite transition in upper amphibolite facies rocks from Broken Hill, Australia. Journal of Metamorphic Geology, 23(7):579-602. https://doi. org/10.1111/j.1525-1314.2005.00597.x

White R.W., Powell R., Holland T.J.B., Worley B.A. 2000. The effect of $\mathrm{TiO}_{2}$ and $\mathrm{Fe}_{2} \mathrm{O}_{3}$ on metapelitic assemblages at greenschist and amphibolite facies conditions: Mineral equilibria calculations in the system $\mathrm{K}_{2} \mathrm{O}-\mathrm{FeO}-\mathrm{MgO}-\mathrm{Al}_{2} \mathrm{O}_{3}-\mathrm{SiO}_{2}-\mathrm{H}_{2} \mathrm{O}-\mathrm{TiO}_{2}-\mathrm{Fe}_{2} \mathrm{O}_{3}$. Journal of Metamorphic Geology, 18(5):497-511. https://doi. org/10.1046/j.1525-1314.2000.00269.x

Whitney D.L. \& Evans B.W. 2010. Abbreviations for names of rock-forming minerals. American Mineralogist, 95(1):185-187. https://doi.org/10.2138/ am.2010.3371

Wiedenbeck M., Allé P., Corfu F., Griffin W.L., Meier M., Oberli F., von Quadt A., Roddick J.C., Spiegel W. 1995. Three natural zircon standards for U-Th- $\mathrm{Pb}$, Lu-Hf, trace element and REE analyses. Geostandards Newsletter, 19(1):1-23. https://doi.org/10.1111/j.1751-908X.1995. tb00147.x 